\title{
The Stringent Response Mediated by (p)ppGpp Is Required for Virulence of Pseudomonas syringae pv. tomato and Its Survival on Tomato
}

\author{
Tiyakhon Chatnaparat, ${ }^{1}$ Zhong $\mathrm{Li}^{2}{ }^{2}$ Schuyler S. Korban,, ${ }^{3,4}$ and Youfu Zhao ${ }^{1}$ \\ ${ }^{1}$ Department of Crop Sciences, University of Illinois at Urbana-Champaign, Urbana, IL 61801, U.S.A.; ${ }^{2}$ Metabolomics Center, \\ Roy J. Carver Biotechnology Center, University of Illinois at-Urbana-Champaign; ${ }^{3}$ Department of Natural Resources and \\ Environmental Sciences, University of Illinois at Urbana-Champaign; ${ }^{4}$ Department of Biology, University of Massachusetts \\ Boston, Boston, MA 02125, U.S.A.
}

Submitted 29 November 2014. Accepted 31 January 2015.

\begin{abstract}
The hypersensitive response and pathogenicity (hrp) type III secretion system (T3SS) is a key pathogenicity factor in Pseudomonas syringae pv. tomato DC3000 (DC3000). In this study, the role of the second messenger (p)ppGpp on virulence and survival of DC3000 was investigated. Results have demonstrated that (p)ppGpp-deficient mutant (ppGpp ${ }^{0}$ ) of DC3000 exhibited lower levels of expression of the T3SS and genes of other virulence traits, such as coronatine toxin. The ppGpp ${ }^{0}$ mutant of DC3000 was greatly impaired in causing disease and in growth in planta. Furthermore, (p)ppGpp was required for swarming motility, pyoverdine production, the oxidative stress response, as well as $\gamma$-amino butyric acid utilization. Screening of amino acids, major signals in activation of ppGpp biosynthesis, revealed that promoter activities of the avrPto gene could be either activated or suppressed by various amino acids in a ppGpp-dependent or -independent manner. Moreover, the ppGpp $^{\circ}$ mutant exhibited increased cell size and decreased survival on plant surfaces. Altogether, these findings indicate that ppGpp acts as an internal signal that regulates the T3SS as well as other virulence factors in pseudomonads and suggest that bacterial pathogens utilize intracellular messengers to sense environmental and nutritional signals for rapid, precise, and reversible control of their pathogenesis and survival.
\end{abstract}

The stringent response is one of the most important global regulator systems that bacteria utilize to orchestrate fine-tuning of their cellular processes in response to changing environmental conditions, especially of limited nutrient conditions. The hallmark of the stringent response is the accumulation of linear nucleotides guanosine tetraphosphate (ppGpp) and guanosine pentaphosphate (pppGpp), collectively known as (p)ppGpp, hereafter referred to as ppGpp, and is also referred to as bacterial alarmone (Potrykus and Cashel 2008). ppGpp is one of several nucleotide second messengers produced in response to environmental stresses to support survival of an organism (Dalebroux and Swanson 2012; Dalebroux et al. 2010). Proteins responsible for ppGpp synthesis and degradation, i.e., RelA/SpoT homolog

Corresponding author: Y. Zhao; Telephone: +1.217.265.9822; Fax: +1.217.333.4582; E-mail: zhao888@illinois.edu

*The $\boldsymbol{e}$-Xtra logo stands for "electronic extra" and indicates that one supplementary figure and one supplementary table are published online.

(C) 2015 The American Phytopathological Society
(RSH) proteins, have been identified in almost all bacterial genomes examined (Atkinson et al. 2011). Under amino acidstarvation conditions, uncharged tRNAs that bind to the ribosomal A site would activate ribosome-associated monofuctional RelA to synthesize ppGpp using ATP and GTP in Escherichia coli (Haseltine and Block 1973; Magnusson et al. 2005). The bifunctional SpoT, containing both synthase and hydrolase activities, is activated in the absence of fatty acid, carbon, phosphorous, and iron, as well as in response to hyperosmotic shock and oxidative stresses (Magnusson et al. 2005; Xiao et al. 1991). In addition, single domain ppGpp-synthesizing or -hydrolyzing RSHs have been found in different bacteria (Atkinson et al. 2011).

During the stringent response, direct interactions between RNA polymerase (RNAP), ppGpp, and a partner transcription factor, DksA, would lead to downregulation of highly expressed stable RNA, DNA replication, ribosome and protein synthesis, and simultaneous upregulation of stress, starvation, and virulence gene expression (Barker et al. 2001; Dalebroux and Swanson 2012; Dalebroux et al. 2010). Therefore, ppGpp acts as a global regulator of cellular transcription reprogramming. ppGpp binds directly to RNAP in $E$. coli to inhibit transcription of genes controlling cell growth and cell division and to activate transcription of amino acid biosynthesis genes (Dalebroux and Swanson 2012; Dalebroux et al. 2010; Potrykus and Cashel 2008). As a result of ppGpp's direct inhibition of RNAP binding to $\sigma^{70}$-dependent stringent promoters, such as rRNA promoters, increased availability of core RNAP to alternative $\sigma$-factors such as RpoN $\left(\sigma^{\mathrm{N}}\right)$, leads to higher levels of expression of alternative $\sigma$-dependent genes (Bernardo et al. 2006; Costanzo et al. 2008; Dalebroux et al. 2010; Gummesson et al. 2009; SzalewskaPalasz et al. 2007).

Following global transcriptome analysis, it has been reported that ppGpp regulates expression of hundreds of genes involved in amino acid biosynthesis, DNA synthesis, fatty acid metabolism, flagella production, universal stress response, survival, and virulence (Aberg et al. 2006; Bremer and Ehrenberg 1995; Chang et al. 2002; Eichel et al. 1999; Hernandez and Bremer 1993; Johansson et al. 2000; Maciąg-Dorszyńska et al. 2013). In plantassociated bacteria, ppGpp influences epiphytic fitness and biocontrol activity in Pseudomonas fluorescens (P. protegens), biofilm formation in $P$. chlororaphis, hydrogen peroxide and antibiotic tolerance in $P$. aeruginosa, and nodulation in Rhizobium etli (Moris et al. 2005; Selin et al. 2010; Takeuchi et al. 2012). In plant-pathogenic bacteria, ppGpp is required for cell-wall degrading enzyme production in Pectobacterium atrosepticum 
and quorum sensing signal degradation in Agrobacterium tumefaciens (Bowden et al. 2013; Wang et al. 2007; Zhang et al. 2004).

P. syringae pv. tomato DC3000 (herein called DC3000), the causal agent of bacterial speck of tomato and Arabidopsis thaliana, is an extracellular hemibiotrophic pathogen. It takes up nutrients from living host tissues, multiplies in the apoplast without apparent host cell death, and reaches high population during late stages of pathogenesis when host cells die and infected tissues exhibit extensive necrosis (Moore et al. 1989; Wang et al. 2002; Whalen et al. 1991). In contrast to other pseudomonads, DC3000 is a relatively weak epiphyte and can only survive on leaf surfaces for a short period of time (Boureau et al. 2002; Manceau and Horvais 1997). As a highly aggressive pathogen, small populations of leaf-associated DC3000 are capable of causing disease symptoms (Xin and $\mathrm{He} 2013$ ). During a compatible interaction, nutritional status of the host, such as high levels of nitrogen $(\mathrm{N})$, as well as favorable environmental conditions often lead to increased disease severity (Xin and He 2013).

DC3000 has been used as a model for studying molecular mechanisms of bacterial pathogenesis as well as for understanding plant-microbe interactions (Xin and He 2013). A functional hypersensitive response and pathogenicity (hrp) type III secretion system (T3SS) is essential for DC3000 to colonize host plants (Alfano and Collmer 2004; Collmer et al. 2000). The T3SS in DC3000 is regulated by the master regulator HrpL, which, in turn, is activated by RpoN along with the enhancer binding proteins HrpR and HrpS (Alarcón-Chaidez et al. 2003; Tang et al. 2006). Other regulators of T3SS include Lon protease (Bretz et al. 2002; Lan et al. 2007) and HrpV, which negatively control HrpR and HrpS activities, respectively (Jovanovic et al. 2011; Ortiz-Martín et al. 2010; Wei et al. 2005). Furthermore, CorR, a response regulator of coronatine toxin, also activates $h r p L$ expression in DC3000 (Peñaloza-Vazquez et al. 2000; Sreedharan et al. 2006). The polyketide coronatine, a virulence factor of DC3000, plays a critical role in opening stomata and in suppressing plant defense responses (Brooks et al. 2004; Uppalapati et al. 2007; Zhao et al. 2003).

In general, earlier studies have reported that the T3SS is rapidly expressed in response to limited nutrients, including low nitrogen and rich plant-derived sugars such as sucrose, fructose, and mannitol, as well as physical contact between host and pathogen (Huynh et al. 1989; Kim et al. 2010; Rahme et al. 1992; Rico and Preston 2008). In contrast, T3SS genes are suppressed in nutrient-rich media containing complex nitrogen sources or certain organic acids, including amino acids (Huynh et al. 1989; Rahme et al. 1992). However, the exact signals that activate the T3SS remain unknown. Moreover, it is also not clear whether or not ppGpp regulates the T3SS or controls virulence in pseudomonads or both. In this study, the role of the bacterial alarmone ppGpp on expression of the T3SS in response to amino acids, virulence, and survival in DC3000 has been investigated.

\section{RESULTS}

\section{The RelA-SpoT system in DC3000.}

Based on bioinformatics analysis of the DC3000 genome sequence, three genes (PSPTO_1694,PSPTO_007, and PSPTO_0856) encoding RSH proteins have been identified (Buell et al. 2003). Following a blast search, PSPTO_1694 (RelA) and PSPTO_0073 (SpoT), corresponding to long RSH proteins, are found to be conserved among all sequenced pseudomonads. Another hypothetical protein with unknown function, PSPTO_0856 (fpRel), is found to contain a single ppGpp synthase domain, belonging to the small alarmone synthetases subgroup (Atkinson et al. 2011). A blast search has also revealed that fpRel is not conserved among sequenced pseudomonads and is only present in a few pseudomonads, including $P$. syringae pv. maculicola ES4326. In contrast, most pseudomonads, including $P$. syringae pv. syringae B728a, contain another small RSH protein, pbcSpo2, having a single hydrolase domain and belonging to the small alarmone hydrolases subgroup (Atkinson et al. 2011).

To study the role of ppGpp-mediated stringent response in the virulence of DC3000, the following mutants of DC3000, relA, relA/spoT, and relA/spoT/fpRel, were generated using overlap extension mutagenesis. However, attempts to generate a single spoT mutant were deemed unsuccessful, as SpoT was the only ppGpp hydrolase present in DC3000 and accumulation of high levels of ppGpp in cells was found to be lethal, as previously reported for E. coli (Xiao et al. 1991). In contrast, a single spoT deletion mutant in both B728a and P. fluorescens was recently reported, possibly due to the presence of pbcSpo2 (T. Chatnaparat, Z. Li, S. S. Korban, and Y. F. Zhao unpublished; Takeuchi et al. 2012).

When intracellular ppGpp levels were determined by liquid chromatography-tandem mass spectrometry (LC-MS/MS), it was found that ppGpp in the DC3000 strain was $10.03 \mathrm{nmol}$ per milliliter at optical density at $600 \mathrm{~nm}\left(\mathrm{OD}_{600}\right)$ when grown in hrp-inducing minimal medium (HMM) for 30 min (Table 1). Levels of ppGpp in the relA mutant were about one third of that in the wild-type (WT) strain; while ppGpp was undetectable in both relA/spoT double and relA/spoT/fpRel triple mutants (Table 1). This could be attributed to limitations in the detection methodology used $\left(<2 \mathrm{nM} / \mathrm{ml}\right.$ at $\left.\mathrm{OD}_{600}\right)$ rather than complete absence of ppGpp in the relA/spoT double mutant. These findings suggested that under HMM conditions, RelA plays a major role in ppGpp synthesis.

\section{Full virulence of DC3000 on tomato requires ppGpp-mediated stringent response.}

To determine the role of the ppGpp-mediated stringent response in virulence of DC3000 on tomato plants, DC3000 WT, relA, relA/spoT, and relA/spoT/fpRel mutants were sprayinoculated onto tomato plants. The WT strain exhibited chlorotic and necrotic lesions (typical disease symptoms) on leaves of tomato plants 7 days postinoculation (dpi) (Fig. 1A). Most leaves inoculated with relA and relA/spoT mutants also exhibited typical disease symptoms. In contrast, inoculation of tomato leaves with the relA/spoT/fpRel mutant (thereafter referred to as $\mathrm{ppGpp}^{0}$ ) yielded only sporadic leaf spots, suggesting that ppGpp contributes to virulence of DC3000 (Fig. 1A). Virulence of the ppGpp $^{0}$ mutant could be partially restored by complementation with relA or fpRel genes in trans (Fig. 1B). These findings suggested that ppGpp synthesized by RelA, SpoT, and fpRel is required for full virulence of DC3000.

To determine whether or not reduced virulence was correlated with bacterial growth in tomato plants, growth of the relA, relA/spoT, and ppGpp ${ }^{0}$ mutants of DC3000 in tomato leaves was compared with that of the WT. Bacterial growth of WT and the relA mutant was similar, reaching approximately $10^{7} \mathrm{CFU} / \mathrm{g} 6 \mathrm{dpi}$ (Fig. 2A), whereas growth of the relA/spoT mutant was about 100 -fold lower than that of the WT strain at 3 and 6 dpi (Fig. 2A). Furthermore, growth of the ppGpp mutant was approximately 1,000-fold lower than that of the WT strain (Fig. 2B). Bacterial growth of the complementation strains of mutants was partially restored in tomato when compared with that of the mutant strains by 6 dpi (Fig. 2A and B). To rule out the likelihood that slow growth of the mutants in plants was due to bacterial growth defects, growth of mutants in M9 minimal medium and in King's medium $\mathrm{B}(\mathrm{KB})$ rich medium were determined. In all strains grown in KB and M9 media, no differences were found (Supplementary Fig. S1) (results for strains grown in HMM medium are provided in Table 2). These results indicated that, although similar symptoms were observed in both the relA/spoT mutant and the WT, bacterial growth was significantly reduced in the mutant, thus suggesting that a certain 
level of ppGpp might be required for growth of bacteria in plants. In addition, these results suggested that fpRel is functional and contributes to ppGpp accumulation in cells.

\section{Expression of T3SS and coronatine genes}

in DC3000 requires ppGpp-mediated stringent response.

As growth and virulence of the $\mathrm{ppGpp}^{0}$ mutant was strongly affected in tomato plants, the role of ppGpp in the regulation of T3SS, effectors, and of other virulence genes was investigated. When promoter activities of the effector avrPto gene were determined in HMM medium by flow cytometry for WT and its mutants carrying avrPto promoter fused to a promoterless green fluorescent protein (GFP) (Table 1), the geometric means of GFP intensities in WT, relA, relA/spoT, and ppGpp ${ }^{0}$ mutants were $112.11,62.91,22.0$, and 9.41, respectively, relative to the vector control (GFP value of about 2.45) in HMM for $3 \mathrm{~h}$ (Table 1). When cells were grown in HMM for $5 \mathrm{~h}$, the geometric means of GFP intensities in WT, relA, and relA/spoT mutants were increased to 330,367 , and 229 , respectively; whereas the

Table 1. Levels of ppGpp and green fluorescent protein (GFP) intensity in wild type (WT) and mutant strains

\begin{tabular}{lccc}
\hline & ppGpp & \multicolumn{2}{c}{ GFP intensity $^{\mathbf{b}}$} \\
\cline { 3 - 4 } Strains & concentration $^{\mathbf{a}}$ & $\mathbf{3 ~ h}$ & $\mathbf{5 ~ h}$ \\
\hline $\mathrm{DC} 3000$ & $10.03 \pm 2.55$ & $112.11 \pm 5.73$ & $330 \pm 9.64$ \\
$\Delta$ relA & $3.21 \pm 1.13$ & $62.91 \pm 2.59$ & $367.78 \pm 4.86$ \\
$\Delta$ relA/spoT & ND & $22.0 \pm 1.16$ & $229.04 \pm 7.85$ \\
$\Delta$ relA/spoT/fpRel & ND & $9.41 \pm 0.14$ & $42 \pm 2.59$ \\
\hline
\end{tabular}

${ }^{a}$ Measured as nmol per milliliter at optical density at $600 \mathrm{~nm}\left(\mathrm{OD}_{600}\right)$. Data are presented as averages of four replicates \pm standard deviation. $\mathrm{ND}=$ not detected due to being below the detection limit $\left(2 \mathrm{nM} / \mathrm{ml}\right.$ at $\left.\mathrm{OD}_{600}\right)$ in liquid chromatography-tandem mass spectrometry.

${ }^{\mathrm{b}}$ GFP intensity was measured by flow cytometry in WT and mutant strains containing the avrPto promoter-GFP reporter construct at time points indicated. geometric mean of GFP intensity in $\mathrm{ppGpp}^{0}$ mutant (42) was about eightfold lower than that of WT (Table 1). These results indicated that ppGpp is required for avrPto gene expression.

When expression of T3SS-related genes was determined using quantitative reverse transcription-polymerase chain reaction (qRT-PCR), levels of expression of $h r p L$ and $h r p Z$ in the $\mathrm{ppGpp}^{0}$ mutant were more than three- and 10-fold lower than those of the WT, respectively; whereas expression of $h r p R$ and $h r p S$ was about twofold lower than those of the WT in HMM at $3 \mathrm{~h}$ postincubation (Fig. 3A). In the relA/spoT mutant, expression of $h r p S$ and $h r p Z$ was about twofold lower than that of the WT, while expression of $h r p R$ and $h r p L$ was only slightly decreased. Furthermore, levels of expression of $h r p R$, $h r p S$, and $h r p Z$ in the relA mutant were similar to those of WT, although $h r p L$ expression was slightly up-regulated when compared with that of the WT (Fig. 3A). These results indicated that ppGpp is required for activating T3SS-related genes in DC3000.

Mutation of the $h r p L$ gene inhibited production of coronatine in DC3000 (Sreedharan et al. 2006). Expression of selected cor genes, including corR (coronatine regulatory gene) and cfI (coronamic acid biosynthesis gene), in both WT and ppGpp mutants in HMM medium was then determined. Expression of both $\operatorname{corR}$ and $c f I$ in the ppGpp ${ }^{0}$ mutant was down-regulated more than fourfold that of the WT (Fig. 3B). Moreover, expression of corR and cfI genes in the relA/spoT mutant was also about twofold lower than that of the WT, while expression of both coronatine genes in the relA mutant was not significantly different from those of the WT (Fig. 3B). These results suggested that ppGpp also influences coronatine gene expression in DC3000.

\section{GABA metabolism in DC3000 is regulated by ppGpp -mediated stringent response.}

It has been reported that the nonprotein amino acid $\gamma$-amino butyric acid (GABA) is highly abundant in tomato apoplasts and that DC3000 is capable of utilizing GABA as a sole carbon and nitrogen source (Park et al. 2010; Rico and Preston 2008).

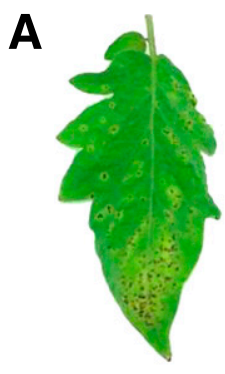

DC3000

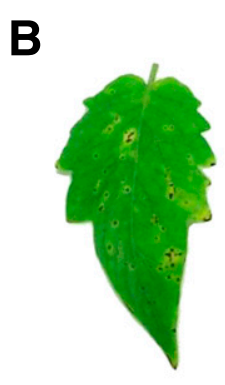

$\Delta$ relA

(pRelA)

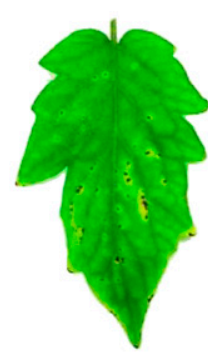

$\Delta$ relA

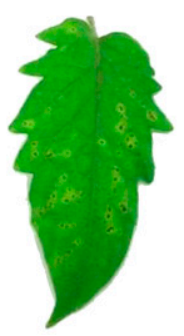

$\Delta$ relA/spoT

(pRelA)
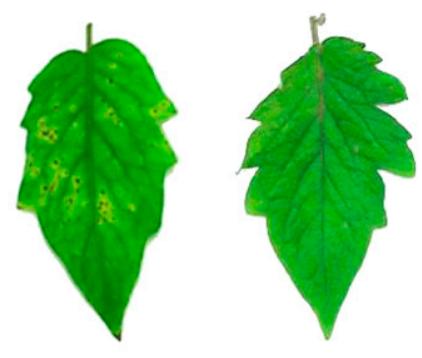

$\Delta$ relA/spot $\Delta$ relA/spot/fpRel
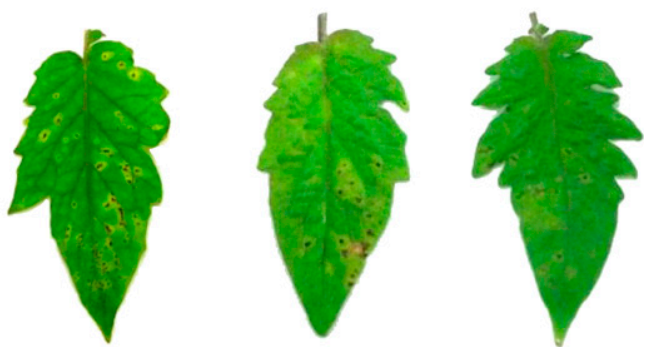

$\Delta$ relA/spot $\Delta$ relA/spoT/fpRel $\Delta$ relA/spoT/fpRel

(pSpoT)

(pRelA) (pFpRel)

Fig. 1. Pathogenicity of P,eudomonas syringae pv. tomato DC3000 (DC3000) wild type (WT), ppGpp mutants, and complementation strains. A, Disease symptoms caused by DC3000 WT, relA, relA/spoT, and relA/spoT/fpRel (ppGpp ${ }^{0}$ ) mutants in susceptible tomato. B, Symptoms caused by the relA, relA/spoT, and relA/spoT/fpRel (ppGpp ${ }^{0}$ ) complementation strains in susceptible tomato. Pictures were taken 7 days postinoculation. The experiment was repeated at least three times and similar results were obtained. 

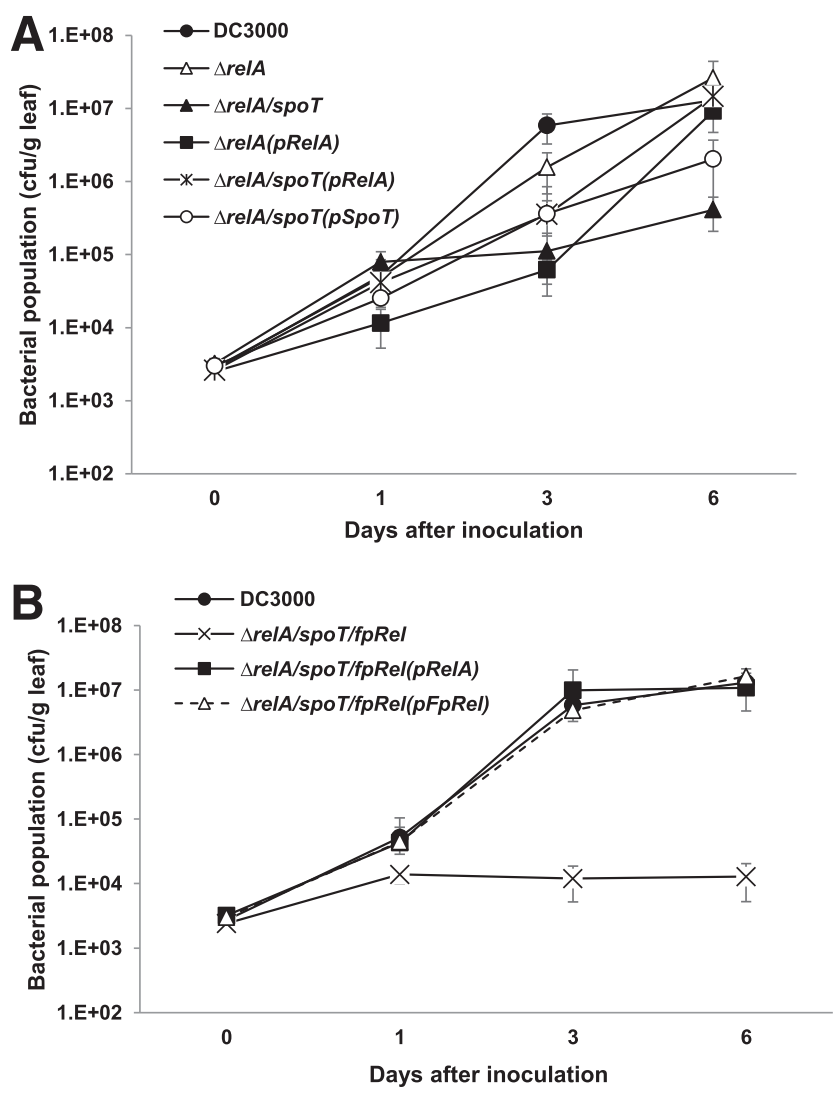

Fig. 2. Growth of Pseudomonas syringae pv. tomato DC3000 (DC3000), ppGpp mutants, and complementation strains. A, Bacterial growth of DC3000 wild type (WT) and relA and relA/spoT mutants, along with their complementation strains in susceptible tomato. B, Bacterial growth of DC3000 WT, the relA/spoT/fpRel $\left(\mathrm{ppGpp}^{0}\right)$ mutant, and complementation strains in susceptible tomato. Bacterial growth was monitored at $0,1,3$, and 6 days postinfiltration. The vertical bars correspond to standard deviations of means.
Expression of gabT (encoding GABA transaminase) genes, including gabT1, gabT2, and gabT3 in WT and mutants, grown in modified mannitol-glutamate (MG) medium, revealed that all three genes in the $\mathrm{ppGpp}^{0}$ mutant were about two to fivefold lower than those of the WT (Fig. 3B). In the relA/spoT mutant, it was found that expression of only gabT2 was about threefold lower than that of the WT. However, expression of all three gabT genes in the relA mutant was similar to that of the WT (Fig. 3B). These results suggested that ppGpp controls GABA gene expression in DC3000. Moreover, when DC3000 and its ppGpp mutants were grown in a minimal medium containing $10 \mathrm{mM}$ GABA as the sole carbon or nitrogen source (Fig. 3C), growth of the WT and the relA mutant was similar, reaching an $\mathrm{OD}_{600}$ of about 0.1 at $24 \mathrm{~h}$ postincubation. In contrast, the $\mathrm{ppGpp}^{0}$ and relA/spoT double mutants failed to grow in GABA (Fig. 3C). Complementation of mutants with both relA and fpRel genes in trans partially restored bacterial growth, except for the triple mutant complemented with fpRel (Fig. 3C). Therefore, it is likely that a certain level of ppGpp is required for growth of bacteria on GABA, as fpRel may only play a minor role in synthesis of ppGpp. These findings suggested that ppGpp is required for GABA metabolism in DC3000.

\section{Amino acids influence T3SS gene expression either through ppGpp or independently.}

Amino acids are known to either affect T3SS gene expression or trigger plant defense responses (Huynh et al. 1989; Rahme et al. 1992; Stauber et al. 2012; Xiao et al. 1992). To assess the influence of amino acids on T3SS expression, the avrPto promoter activities in both the WT and the $\mathrm{ppGpp}^{0}$ mutant, grown in HMM supplemented with either an individual amino acid or GABA, were determined by flow cytometry. Based on means of GFP intensities in the $\mathrm{ppGpp}^{0}$ mutant when compared with those of the WT, amino acids were classified into four groups (Table 2). Group I, including aspartic acid, glutamic acid, asparagine, and GABA, strongly induced avrPto promoter activities in both the WT and the ppGpp ${ }^{0}$ mutant as compared with

Table 2. Green fluorescent protein (GFP) intensity and growth of wild type (WT) and ppGpp ${ }^{0}$ mutant strains grown in $h r p$-inducing minimal medium (HMM) supplemented with different amino acids

\begin{tabular}{|c|c|c|c|c|c|}
\hline \multirow[b]{2}{*}{ Media $^{a}$} & \multicolumn{2}{|c|}{ GFP intensity ${ }^{b}$} & \multicolumn{2}{|c|}{ Growth } & \multirow[b]{2}{*}{ Growth of $r p o N_{-}{ }^{c}$} \\
\hline & DC3000 & $\Delta r e l A / s p o T / f p R e l$ & DC3000 & $\Delta r e l A / s p o T / f p R e l$ & \\
\hline HMM & $112.11 \pm 5.73$ & $9.41 \pm 0.14$ & 0.12 & 0.11 & $\ldots$ \\
\hline Aspartic Acid & $688.26 \pm 38.22$ & $785.80 \pm 28.19$ & 0.35 & 0.48 & - \\
\hline Glutamic Acid & $618.83 \pm 13.75$ & $278.24 \pm 12.15$ & 0.80 & 0.81 & + \\
\hline Asparagine & $589.66 \pm 22.99$ & $245.02 \pm 2.93$ & 0.28 & 0.28 & + \\
\hline GABA & $406.12 \pm 4.48$ & $387.57 \pm 9.45$ & 0.66 & 0.48 & $\ldots$ \\
\hline Glycine & $335.72 \pm 8.14$ & $36.02 \pm 4.07$ & 0.17 & 0.21 & $\ldots$ \\
\hline Glutamine & $327.50 \pm 0.41$ & $28.16 \pm 28.40$ & 0.70 & 0.90 & + \\
\hline Lysine & $293.29 \pm 11.02$ & $22.02 \pm 0.11$ & 0.21 & 0.16 & + \\
\hline Threonine & $250.10 \pm 0.04$ & $20.00 \pm 0.12$ & 0.15 & 0.12 & W \\
\hline Arginine & $221.94 \pm 1.17$ & $40.02 \pm 1.32$ & 0.18 & 0.16 & + \\
\hline Serine & $349.52 \pm 34.17$ & $7.25 \pm 0.08$ & 0.62 & 0.79 & W \\
\hline Proline & $311.88 \pm 25.29$ & $9.62 \pm 0.06$ & 0.81 & 0.27 & - \\
\hline Leucine & $242.39 \pm 7.33$ & $10.68 \pm 0.31$ & 0.23 & 0.13 & W \\
\hline Histidine & $232.78 \pm 11.67$ & $7.68 \pm 0.04$ & 0.22 & 0.08 & - \\
\hline Phenylalanine & $228.72 \pm 2.36$ & $8.11 \pm 0.03$ & 0.24 & 0.07 & - \\
\hline Alanine & $163.16 \pm 0.46$ & $7.79 \pm 0.17$ & 0.32 & 0.07 & W \\
\hline Methionine & $127.04 \pm 3.93$ & $7.63 \pm 0.09$ & 0.13 & 0.05 & - \\
\hline Isoleucine & $96.47 \pm 1.95$ & $8.04 \pm 0.01$ & 0.05 & 0.05 & W \\
\hline Cysteine & $22.64 \pm 0.86$ & $17.60 \pm 0.62$ & 0.06 & 0.04 & $\ldots$ \\
\hline Valine & $12.04 \pm 0.08$ & $9.21 \pm 0.01$ & 0.07 & 0.05 & $\ldots$ \\
\hline
\end{tabular}

${ }^{\mathrm{a}}$ Each of the amino acids and GABA were used at $10 \mathrm{mM}$. Cultures $(3 \mathrm{ml})$ were shaken $\left(250 \mathrm{rpm}, 22^{\circ} \mathrm{C}\right)$ for $3 \mathrm{~h}$.

${ }^{\mathrm{b}}$ GFP intensities of the WT and mutant strains containing the avrPto promoter-GFP reporter construct were measured by flow cytometry.

${ }^{\mathrm{c}}$ For RpoN mutant, $+=$ growth; $\mathrm{W}=$ weak; $-=$ lack of growth on plates containing specific amino acid, data obtained from Hendrickson et al. (2000a). Ellipses (...) indicate not determined. 
those grown in HMM alone. Group II, consisting of glycine, glutamine, lysine, threonine, and arginine, exhibited slightly elevated avrPto promoter activities in the $\mathrm{ppGpp}^{0}$ mutant compared with cells grown in HMM alone; however, the avrPto promoter activity was strongly enhanced in the WT. Group III, including serine, proline, leucine, histidine, alanine, and phenylalanine, influenced avrPto promoter activities only in the WT. Finally, Group IV, consisting of methionine, isoleucine, cysteine, and valine, either had no effects or suppressed avrPto promoter activities in the WT only. These results indicated that amino acids could either activate or suppress T3SS expression in either ppGpp-dependent or -independent manners. Furthermore, bacterial growth of the WT and the $\mathrm{ppGpp}^{0}$ mutant was influenced by adding amino acids into the HMM medium (Table 2). The ppGpp $^{0}$ mutant but not the WT was unable to grow in HMM supplemented with proline, histidine, phenylalanine, alanine, and methionine; whereas, both the WT and the ppGpp ${ }^{0}$ mutant were unable to grow in HMM supplemented with isoleucine, cysteine, and valine (Table 2). These results indicated that ppGpp serves as a signal that influences amino acid utilization in DC3000.

\section{Swarming motility, pyoverdine production, and resistance to hydrogen peroxide are dependent on ppGpp-mediated stringent response.}

The $\mathrm{ppGpp}^{0}$ mutant was found to be unable to swarm, while the relA and relA/spoT mutants showed reduced swarming motilities relative to those of the WT (Fig. 4A and B), thus

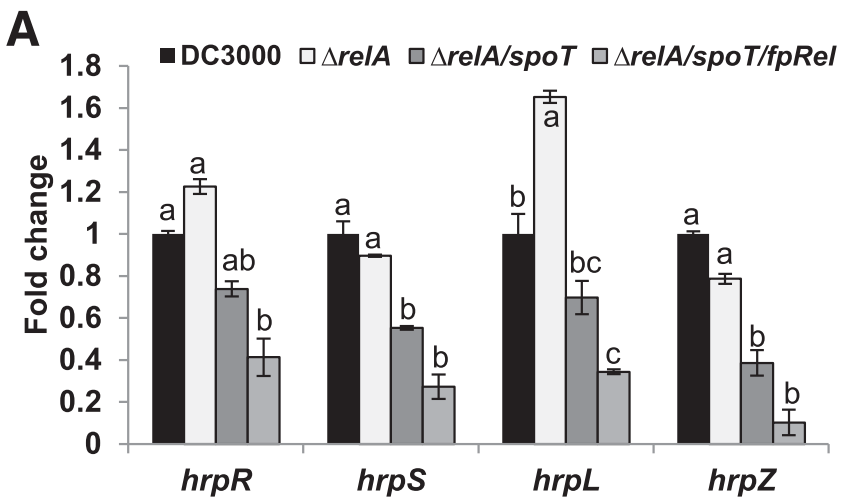

B

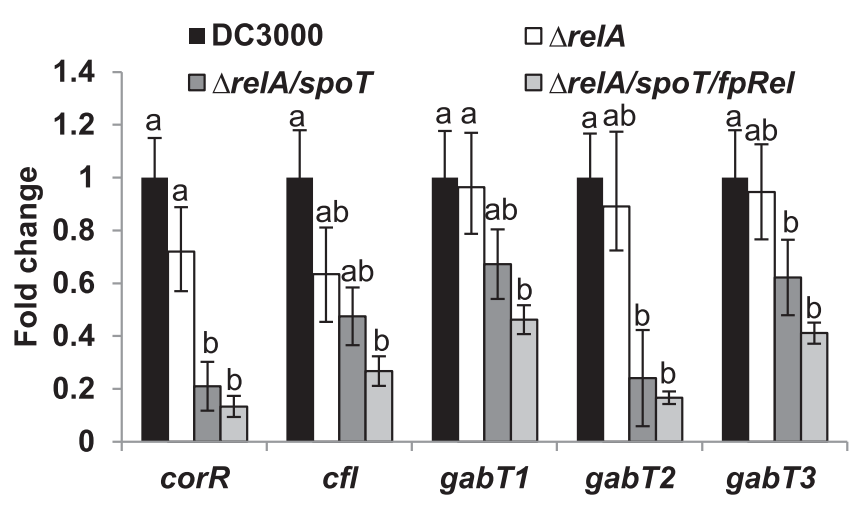

suggesting that ppGpp controls swarming motility in DC3000. Complementation of the $\mathrm{ppGpp}^{0}$ strain by expressing either relA or $f p R e l$ in trans partially restored swarming motility, whereas complementation of the relA/spoT mutant by expressing $\mathrm{relA}$ and spoT in trans resulted in reduced swarming motility (Fig. 4A and B). When the effects of ppGpp on pyoverdine production in DC3000 and its mutants were determined, it was found that pyoverdine production was reduced by three- to 10 -fold in the relA, relA/spoT, and ppGpp ${ }^{0}$ mutants as compared with those of the WT under low-iron conditions (Fig. 5A). Complementation of mutants with relA and fpRel but not of spoT in trans restored pyoverdine levels in ppGpp mutant strains (Fig. 5A). These results suggested that ppGpp affects pyoverdine production, likely in response to availability of iron.

It has been reported that ppGpp is involved in hydrogen peroxide tolerance in Pseudomonas spp. (Khakimova et al. 2013). Following exposure to $1 \mathrm{mM} \mathrm{H} \mathrm{O}_{2}$ for $15 \mathrm{~min}$, it was observed that only $0.69 \%$ of the $\mathrm{ppGpp}^{0}$ mutant survived compared with $29.5 \%$ of the WT (Fig. 5B). Survival of the relA/spoT mutant was about $19.5 \%$, while survival of the relA mutant was not significantly different $(31 \%)$ from that of the WT. Complementation of the ppGpp ${ }^{0}$ mutant by expressing relA and fpRel in trans partially recovered its survival (Fig. 5B). However, presence of spoT in trans in the relA/spoT mutant led to higher sensitivity to $\mathrm{H}_{2} \mathrm{O}_{2}$ when compared with the relA/spoT mutant (Fig. 5B). These results indicated that $\mathrm{ppGpp}$ is required for resistance to hydrogen peroxide in DC3000.

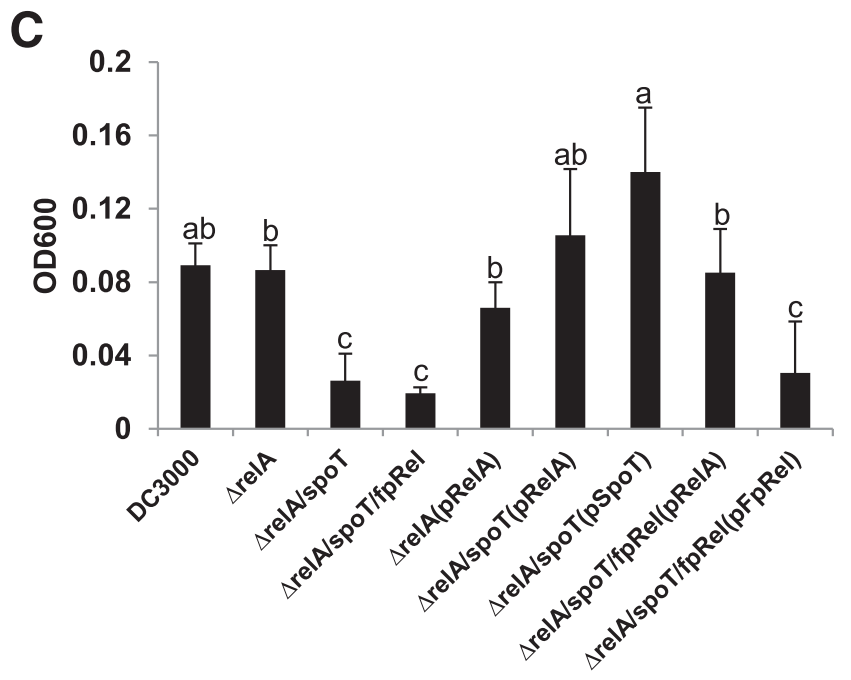

Fig. 3. Virulence gene expression of Pseudomonas syringae pv. tomato DC3000 (DC3000) and ppGpp mutants. A, Expression of type III secretion system genes in the relA, relA/spoT, and relA/spoT/fpRel $\left(\mathrm{ppGpp}^{0}\right.$ ) mutant strains as compared with DC3000 wild type (WT) strain grown in hrp-inducing minimal medium medium $3 \mathrm{~h}$ postinoculation determined by quantitative reverse transcription-polymerase chain reaction (qRT-PCR). B, Expression of corR, cfI, gabT1, gabT2, and gabT3 in the relA, relA/spoT, and relA/spoT/fpRel $\left(\mathrm{ppGpp}^{0}\right)$ mutant strains as compared with DC3000 WT strain by qRT-PCR. The rpoD gene was used as a control. Vertical bars represent the standard deviations of mean ratio. Similar results were obtained in repeated independent experiments. One-way analysis of variance (ANOVA) and the Student-Newmans-Kleus test $(P=0.05)$ was used to analyze qRT-PCR data. For each gene tested in WT and mutants, fold changes marked with the same letter were not significantly different $(P<0.05)$. C, Growth of DC3000 WT, ppGpp mutants, and complementation strains in minimal medium supplemented with $10 \mathrm{mM} \mathrm{GABA}$ at $28^{\circ} \mathrm{C}$ for $24 \mathrm{~h}$. Vertical bars correspond to standard deviations. One-way ANOVA and the Student-Newmans-Kleus test $(P=0.05)$ were used to analyze growth data. Changes marked with the same letter were not significantly different $(P<0.05)$. 
Cell size and survival of DC3000

on tomato is controlled by ppGpp.

It has been reported that bacterial cells protect themselves from a wide range of adverse conditions by adjusting their cell sizes, thereby promoting survival under these adverse conditions (Dalebroux and Swanson 2012; Potrykus et al. 2011). Using epifluorescence microscopy, cell lengths of DC3000 WT and its ppGpp mutants constitutively expressing GFP were determined in both $\mathrm{KB}$ and $\mathrm{HMM}$ medium. In $\mathrm{KB}$ medium, no significant differences were found for bacterial cell lengths for both the WT and its ppGpp mutants, ranging from 2.75 to 2.89 (data not shown). When cells were grown in HMM, lengths of WT cells were significantly shortened to $1.59 \mu \mathrm{m}$ (Fig. 6A and B). Mean cell lengths for relA and relA/spoT mutants were about $2.17 \mu \mathrm{m}$, slightly shorter than those grown in $\mathrm{KB}$, whereas cell length of the $\mathrm{ppGpp}^{0}$ mutant of DC3000 was $2.59 \mu \mathrm{m}$ (Fig. 6). These results indicated that $\mathrm{ppGpp}$ controls cell size under nutrient limited conditions in DC3000.

When confocal microscopy was used in a time-course study to assess whether or not ppGpp influenced bacterial cell survival on either host or nonhost plant leaf surfaces, it was found that, at $24 \mathrm{~h}$ postinoculation (hpi), WT viable cells (green in color) were detected in small groups along epidermal cell surfaces (Fig. 7A). At 48 hpi, most WT cells were found to be dead (red in color) on leaf surfaces but there were small numbers of viable cells (Fig. 7B). At 96 hpi, abundant small-sized viable
WT cells were observed as large aggregates along newly formed lesions (Fig. 7C). In contrast, most ppGpp ${ }^{0}$ mutant cells were found to be dead on leaf surfaces at each time point (Fig. 7D, E, and F). On nonhost tobacco leaf surfaces, some WT cells were found to be viable, while most $\mathrm{ppGpp}^{0}$ mutant cells were found to be dead at $24 \mathrm{~h}$ (Fig. $7 \mathrm{G}$ and $\mathrm{H}$ ). These results suggested that ppGpp is required for survival of DC3000 on both host and nonhost plants.

\section{DISCUSSION}

In DC3000, T3SS is quickly activated by a sigma factor cascade (RpoN and HrpL) when in contact with plants or in HMM medium (Alarcón-Chaidez et al. 2003; Ferreira et al. 2006; Hendrickson et al. 2000a; Jovanovic et al. 2011; Rahme et al. 1992; Tang et al. 2006). The proposed signals for activating T3SS, which include low nutrients and oxidative stress, are similar to those signals sensed by RSH proteins. In this study, it was demonstrated that bacteria deficient in their ability to produce ppGpp exhibit lower levels of expression of T3SS and of other virulence factors. Furthermore, it was found that ppGpp controls both cell size and survival both in vitro and on plant surfaces and is required for various stress responses. These findings indicate that ppGpp serves as a critical internal signal that coordinates expression of virulence factors in DC3000 in response to plant stimuli. Moreover, this suggests that bacterial pathogens utilize intracellular
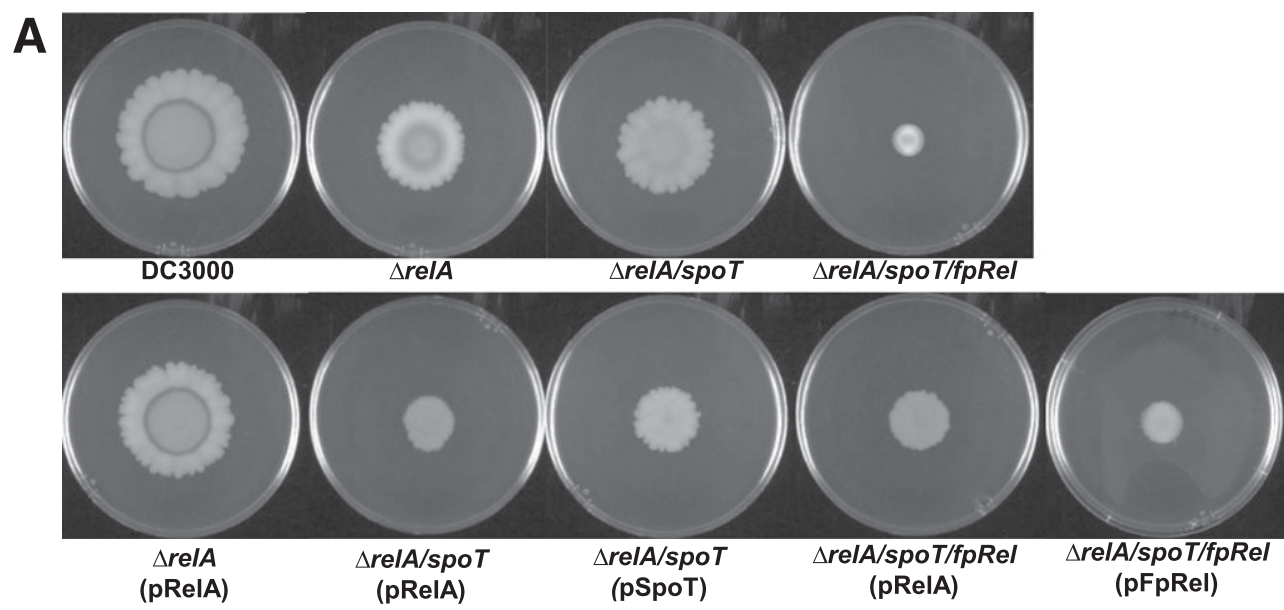

B 6

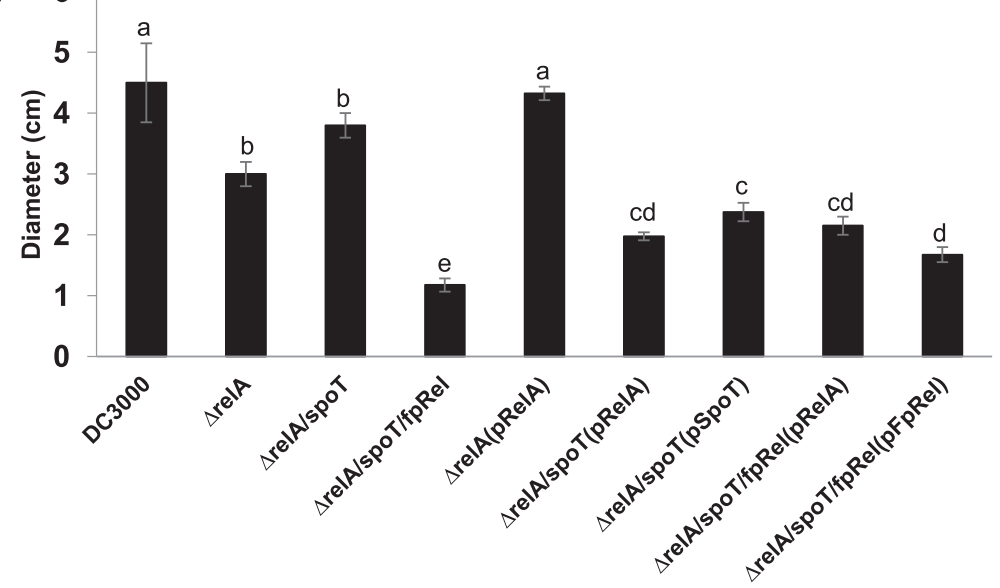

Fig. 4. ppGpp controls swarming motility. A, Swarming motility of Pseudomonas syringae pv. tomato DC3000 (DC3000) wild type (WT), the relA, relA/spoT, and relA/spoT/fpRel $\left(\mathrm{ppGpp}^{0}\right)$ mutants, and their complementation strains on swarming plates (King's medium B containing $0.4 \%$ agar) $24 \mathrm{~h}$ postinoculation (hpi). The experiments were repeated at least three times with similar results. B, Swarming diameter of DC3000 WT, the relA, relA/spoT, and relA/spoT/fpRel $\left(\mathrm{ppGpp}^{0}\right)$ mutant strains, and their complementation strains $24 \mathrm{hpi}$. One-way analysis of variance and the Student-Newmans-Kleus test $(P=0.05)$ was used to analyze the data. For WT, mutants, and complementation strains, changes marked with the same letter were not significantly different $(P<0.05)$. 
messengers to sense environmental and nutritional signals for rapid, precise, and reversible control of pathogenesis and survival.

Unlike most proteobacteria, which contain only RelA/SpoT, a novel small ppGpp synthase, fpRel, is present in the genome of DC3000. Although levels of ppGpp produced in relA/spoT and $\mathrm{relA} / \mathrm{spoT/fpRel}\left(\mathrm{ppGpp}^{0}\right)$ mutants have been found to be undetectable by LC-MS/MS, the relA/spoT mutant was found to be capable of causing disease while the $\mathrm{ppGpp}^{0}$ mutant was not. This indirectly suggests that fpRel is functional and that it is required for ppGpp synthesis in DC3000. Unfortunately, we could not generate a spoT null mutant in DC3000, as it has been reported that the E. coli spoT mutant is lethal due to accumulation of high levels of ppGpp (Xiao et al. 1991). This finding is in contrast with what has been observed in P. syringae B728a,

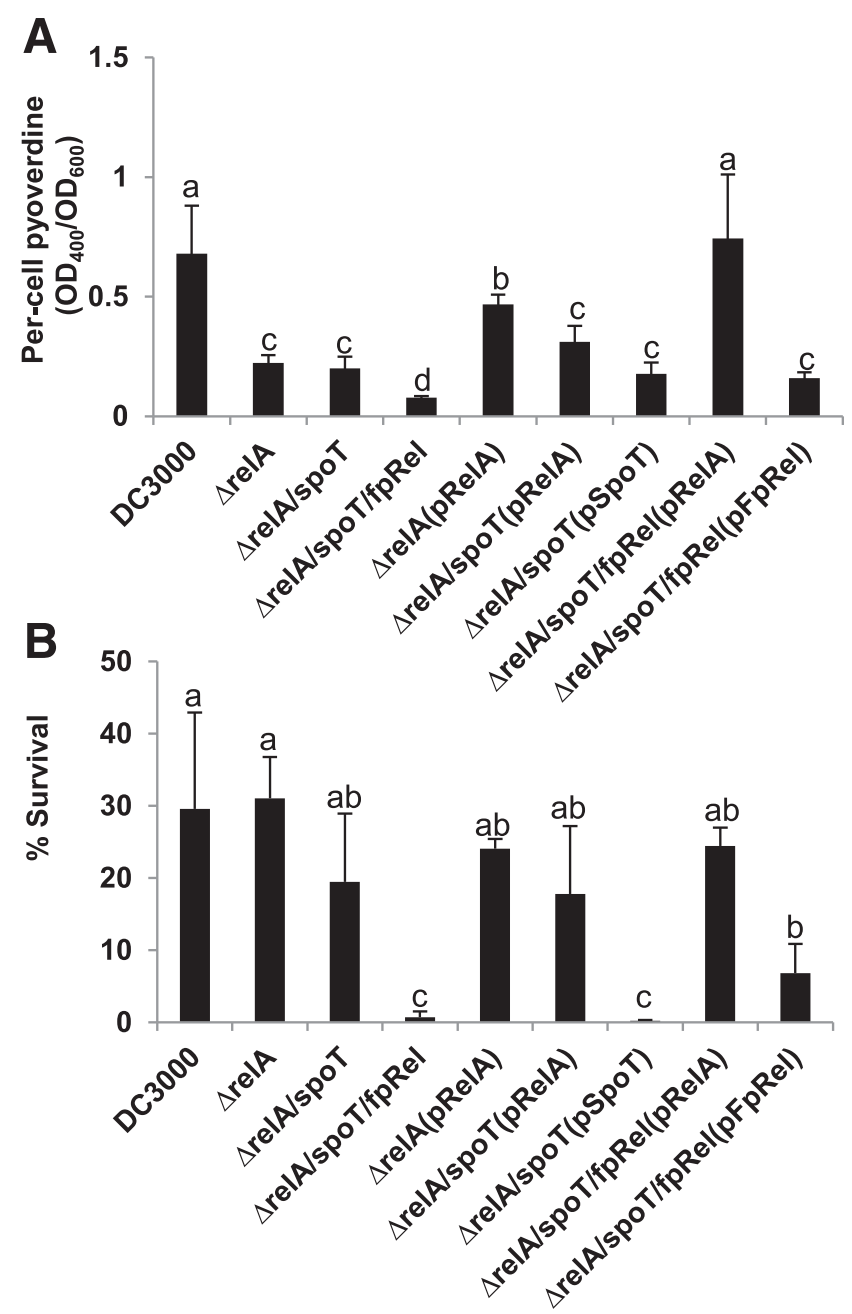

Fig. 5. ppGpp regulates pyoverdine production and oxidative stress tolerance. A, Pyoverdine production by Pseudomonas syringae pv. tomato DC3000 (DC3000) wild type (WT), the relA, relA/spoT, and relA/spoT/ fpRel $\left(\mathrm{ppGpp}^{0}\right)$ mutants, and their complementation strains grown in mannitol-glutamate (MG) medium at $28^{\circ} \mathrm{C}$ for $24 \mathrm{~h}$. Pyoverdine levels were determined by measuring absorbance at $405 \mathrm{~nm}\left(\mathrm{~A}_{405}\right)$ of cell-free culture supernatants in MG medium normalized by the absorbance at $600 \mathrm{~nm}$ $\left(\mathrm{A}_{600}\right)$ of the bacterial culture. Data were presented as relative fluorescence levels $\left(\mathrm{A}_{405} / \mathrm{A}_{600}\right)$. The experiments were repeated three times with similar results. B, Survival of DC3000 WT, the relA, relA/spoT, and relA/spoT/ fpRel $\left(\mathrm{ppGpp}^{0}\right)$ mutants, and their complementation strains after exposure to $1 \mathrm{mM} \mathrm{H}_{2} \mathrm{O}_{2}$ for $15 \mathrm{~min}$. Similar results were obtained in repeated independent experiments. The vertical bars represent the standard deviation of the mean. One-way analysis of variance and the Student-Newmans-Kleus test $(P=0.05)$ were used to analyze the data. For WT, mutants, and complementation strains, changes marked with the same letter were not significantly different $(P<0.05)$. in which a spoT mutant was successfully generated, possibly due to the presence of the pbcSpo2 gene encoding a small ppGpp hydrolase (T. Chatnaparat, Z. Li, S. S. Korban, and Y. F. Zhao unpublished). On the other hand, mutation of the relA gene of DC3000 did not affect bacterial growth in planta while both relA/ spoT and $\mathrm{ppGpp}^{0}$ mutants exhibited gradually reduced growth in planta. This indicates that low levels of ppGpp in the relA mutant could be produced by both SpoT and fpRel, which may be sufficient to contribute to both virulence and growth of DC3000.

In this study, cell size (length) and survival as well as resistance to stress of DC3000 and the ppGpp mutants were found to be correlated with levels of ppGpp produced in cells (Figs. 6 and 7; Table 1). WT cells exhibited short cell lengths both in HMM medium and in planta and survived well on leaf surfaces, whereas $\mathrm{ppGpp}^{0}$ mutant cells were longer but could not survive on leaf surfaces, thus indicating that plant leaf surfaces offer a nutrient-limited habitat. These results were consistent with previous reports found in both $P$. syringae and in $E$. coli (Monier and Lindow 2003b; Traxler et al. 2008), further suggesting that ppGpp controls bacterial cell size and survival under nutrient-limited conditions. Earlier, it has been reported that
A
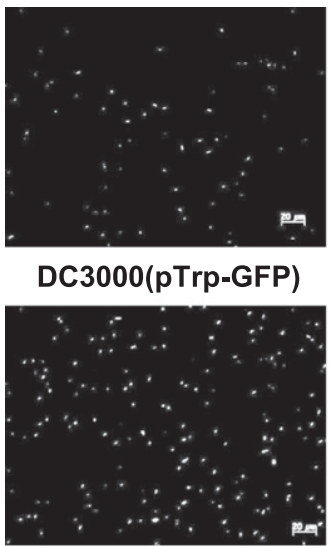

$\Delta r e / A(p T r p-G F P)$

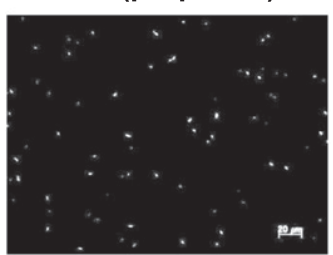

$\Delta$ relA/spot(pTrp-GFP)

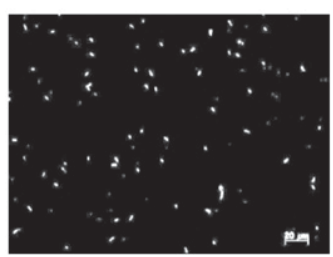

$\Delta r$ IA/spoT/fpRel(pTrp-GFP)
B
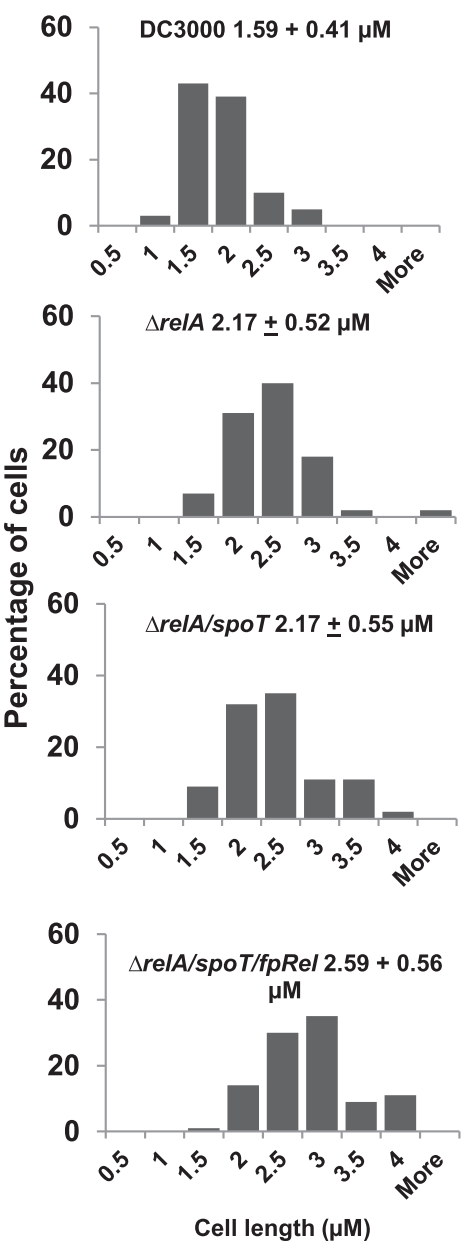

Fig. 6. ppGpp controls cell size in medium. A, Microscopy images of Pseudomonas syringae pv. tomato DC3000 (DC3000) wild type (WT) and the $\mathrm{relA}$, relA/spoT, and relA/spoT/fpRel ( $\mathrm{ppGpp}^{0}$ ) mutant strains constitutively expressing green fluorescent protein (GFP) observed by epifluorescence microscope after growth in $h r p$-inducing minimal medium (HMM) medium for $4 \mathrm{~h}$. Pictures were taken at $200 \times$ magnification with a scale bar of $20 \mu \mathrm{m}$. B, Distribution of bacterial sizes and average bacterial cell lengths of DC3000 WT and the relA, relA/spoT, and ppGpp mutant strains constitutively expressing GFP in HMM media. 
smaller-sized cells were more resistant to various stress conditions (Crompton et al. 2014; Hase 1999; Jubair et al. 2012; Monier and Lindow 2003b; Steinberger et al. 2002) and that ppGpp controlled antibiotic tolerance and oxidative and osmotic stresses (Khakimova et al. 2013; Vercruysse et al. 2011) as well as motility and siderophore production (Magnusson et al. 2007; Takeuchi et al. 2012; Vogt et al. 2011; Wang et al. 2007). In DC3000, it was found that ppGpp is required for swarming motility, pyoverdine production, and oxidative stress responses. These results suggested that DC3000 might require ppGpp accumulation to coregulate cell size and resistance to environmental stresses on tomato, thus contributing to overall survival.

DC3000 employs both T3SS and phytotoxin coronatine to cause disease (Elizabeth and Bender 2007; Melotto et al. 2008; Uppalapati et al. 2007; Zhao et al. 2003). Several regulatory proteins, including HrpL and RpoN, control expression of T3SS and coronatine genes (Chatterjee et al. 2003; Hendrickson et al. 2000b; Sreedharan et al. 2006). In this study, it has been demonstrated that transcription of $h r p L, h r p R S, h r p Z$, and avrPto as well as of $\operatorname{cor} R$ and $c f l$ was under positive regulation of ppGpp. Moreover, these regulatory effects correlated with levels of ppGpp in cells, suggesting that ppGpp is required for activating T3SS and coronatine gene expression. These findings were consistent with previous reports indicating that activation of $h r p L$ transcription occurred early on in the infection process
(Sreedharan et al. 2006). Therefore, ppGpp levels in cells are critically important for stimulating early induction of T3SS and of coronatine genes. As corR and $h r p L$ regulate each other (Sreedharan et al. 2006), the effects of ppGpp on coronatine gene expression in DC3000 are likely to be mediated by ppGpp through the RpoN-HrpL sigma factor cascade. In addition, recent studies have shown that ppGpp is involved in the Gac/Rsm signal transduction pathway and that mutation of GacA in DC3000 suppresses expression of rpoN, hrpRS, hrpL, and coronatine genes (corR and corS) (Chatterjee et al. 2003; Takeuchi et al. 2012). Therefore, it is likely that ppGpp may interact with the Gac/Rsm system to regulate virulence factors in DC3000. However, this deserves further investigation.

The most abundant amino acids in tomato apoplasts are GABA and aspartic and glutamic acids, which could be used by DC3000 as carbon and nitrogen sources (Rico and Preston 2008). In addition, genes involved in GABA metabolism of B728a are up-regulated in planta, thus indicating that GABA is being utilized as a nutrient source (Yu et al. 2013). In this study, both relA/ spoT and $\mathrm{ppGpp}^{0}$ mutants failed to grow in a medium containing only GABA as a sole carbon or nitrogen source. Furthermore, expression of three gabT genes encoding GABA transaminase in DC3000 was under positive regulation of ppGpp and this correlated well with ppGpp levels. It has been reported that gabT2 plays a major role in GABA utilization in DC3000 (Park et al. 2010). This is consistent with our findings that expression of
A

24h

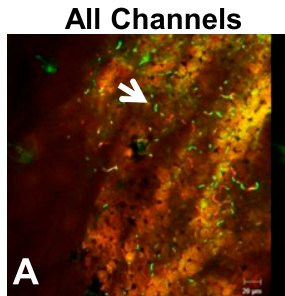

A488

A568

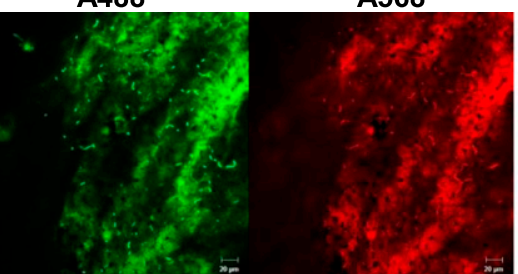

48h

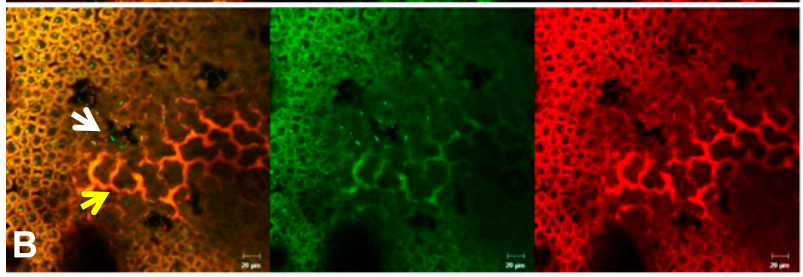

$96 \mathrm{~h}$
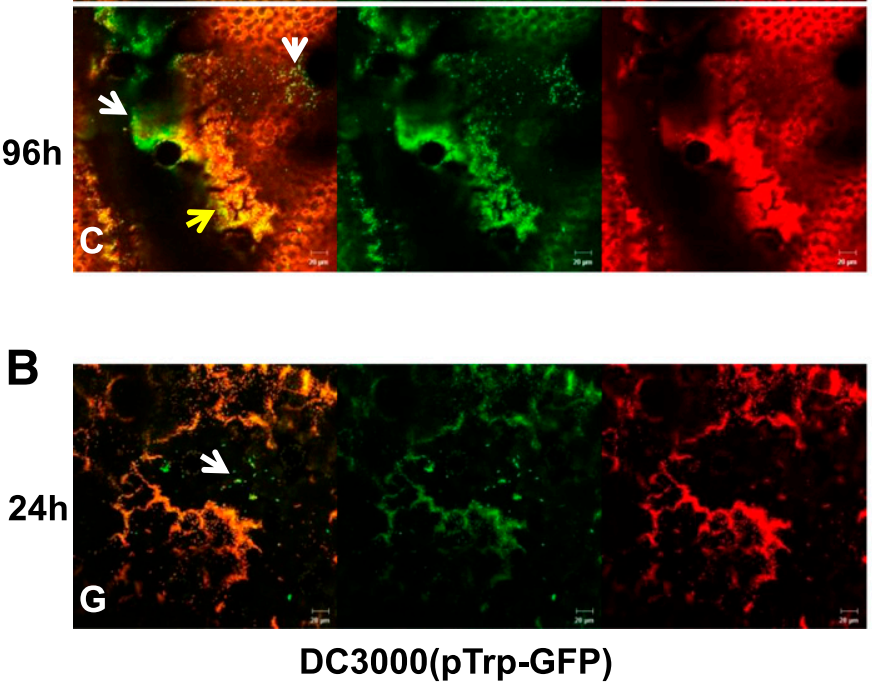
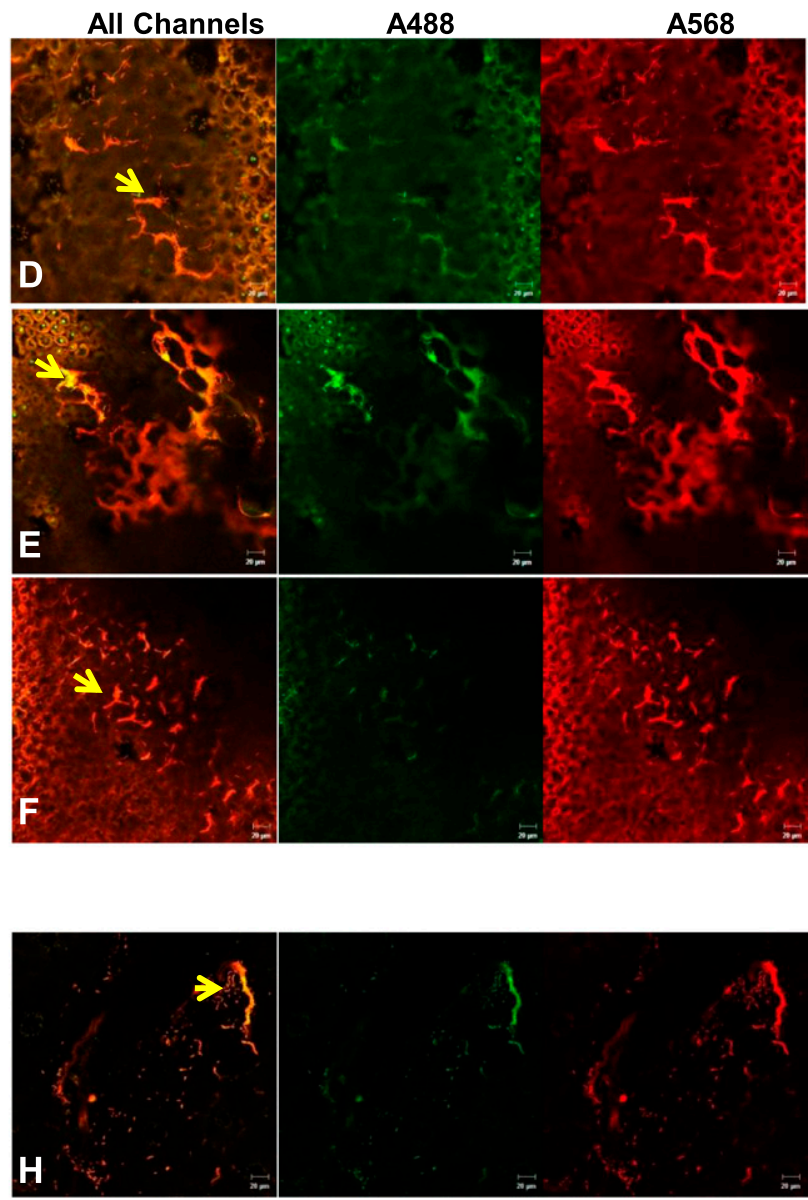

$\Delta r e I A / s p o T / f p R e /(p T r p-G F P)$

Fig. 7. ppGpp mediates survival on plants. A, Microscopy images of Pseudomonas syringae pv. tomato DC3000 (DC3000) (A to C) and the relA/spoT/fpRel (ppGpp ${ }^{0}$ ) mutant strain (D to F) constitutively expressing green fluorescent protein (GFP) observed by confocal laser scanning microscopy at 24, 48 , and $96 \mathrm{~h}$ following spray inoculation on tomato. B, Microscopy images of DC3000 (G) and the ppGpp mutant strain $(\mathrm{H})$ constitutively expressing GFP and observed by confocal laser scanning microscopy $24 \mathrm{~h}$ following spray inoculation on tobacco leaf surface. GFP-labeled bacterial cells were green, dead bacterial cells stained with propidium iodide were red, and leaf cells were either red or black in color. White arrows indicate GFP-labeled bacteria. Pictures were taken at $200 \times$ magnification with a scale bar of $20 \mu \mathrm{m}$. 
gabT2 in the relA/spoT and ppGpp ${ }^{0}$ plants was significantly reduced. Furthermore, higher levels of GABA in plants can suppress T3SS in DC3000 and, also, quash virulence in Agrobacterium tumefaciens (Chevrot et al. 2006; Park et al. 2010; Wang et al. 2006), suggesting that ppGpp may be required for GABA utilization to suppress plant defense responses mediated by GABA and to promote bacterial growth in planta.

Amino acids are known to affect T3SS gene expression (Huynh et al. 1989; Rahme et al. 1992; Stauber et al. 2012; Xiao et al. 1992). Our results have revealed that amino acids can either activate or repress T3SS expression in both ppGpp-dependent and -independent manners (Table 2). GABA, aspartic acid, glutamic acid, and asparagine have strongly activated expression of T3SS in HMM and promoted growth of both the WT and the ppGpp $^{0}$ strain. This finding is consistent with a previous report indicating that aspartic and pyroglutamic acids in Arabidopsis along with fructose or mannitol but not alone strongly induced avrPto expression in DC3000 (Anderson et al. 2014). However, our results were in contrast with other previous findings indicating that, in $P$. syringae pv. glycinea, both aspartic and glutamic acids inhibit T3SS expression (Huynh et al. 1989). At first glance, it appears that our GABA results are in contrast with those reported previously, i.e., GABA suppresses T3SS in DC3000 (Park et al. 2010). However, this discrepancy may be attributed to the different media used in these studies (HMM versus MG), as the latter medium contains glutamate, which, along with GABA, may contribute to different T3SS expression, but this needs to be further explored.

Based on the above and previous findings, the following model is proposed to illustrate how DC3000 perceives host and environmental signals and coordinates virulence and survival through second-messenger ppGpp (Fig. 8). A plant phyllosphere has long been deemed as a stress environment, as nutrients are limited. Upon contact with plant surfaces, it is likely that the relA, spoT, and fpRel genes are immediately activated when DC3000 cells sense the limited-nutrient environment, iron availability, and oxidative stress conditions, thereby triggering the ppGppmediated stringent response. In turn, the stringent response indirectly promotes alternative sigma factor activities, including RpoN and HrpL, leading to expression of T3SS and of other virulence factors as well as of stress-related genes. It is known that the genome of DC3000 contains 15 sigma factors, including 10 extracytoplasmic function (ECF) sigma factors (Oguiza et al.
2005). These ECF sigma factors are involved in regulating T3SS gene expression (HrpL), iron transport systems (PvdS, PSPTO1203, PSPTO1209, PSPTO1286, and PSPTO0444), outer membrane modifications ( $\mathrm{SigX}$ and $\mathrm{AlgU}$ ), as well as unknown functions (PSPTO1043 and PSPTO4224) (Markel et al. 2011, 2013; Oguiza et al. 2005). In addition, the DC3000 genome encodes over $12 \%$ of the genes required for rapid adaptation to diverse environments during epiphytic growth and pathogenesis (Buell et al. 2003). Together with other global regulatory systems, such as the Gac/Rsm system, ppGpp-mediated stringent response coordinately regulates nutrient acquisition through different bacterial enhancer binding proteins, such as $\mathrm{NtrC}$, as well as various stress responses, including siderophore production, tolerance to oxidative stress, cell size, and survival. These findings suggest that signals triggering ppGpp biosynthesis are most likely to be responsible for activation of T3SS in DC3000. Therefore, future studies should identify these signals, which, possibly, are multifaceted.

\section{MATERIALS AND METHODS}

Bacterial strains, plasmids, and recombinant techniques.

Bacterial strains and plasmids used in this study are listed in Table 3. P. syringae pv. tomato strains were cultured on $\mathrm{KB}$ or MG medium at $28^{\circ} \mathrm{C}$ (Park et al. 2010) or in $\mathrm{HMM}$ at $22^{\circ} \mathrm{C}$ (Huynh et al. 1989). E. coli strains were routinely grown in Luria Bertani medium at $37^{\circ} \mathrm{C}$. Bacterial growth was monitored by measuring absorbance of cell suspensions at $600 \mathrm{~nm}$. All primers used in this study are listed in Supplementary Table S1. Antibiotics were added to medium at the following concentrations $(\mu \mathrm{g} / \mathrm{ml})$ : kanamycin, 50; rifampicin, 100; tetracycline, 15; and spectinomycin, 100. All DNA manipulations, including DNA isolation, plasmid extraction, restriction enzyme digestion, ligation, and gel electrophoresis were performed as described previously (Sambrook et al. 1989).

\section{Construction of relA, relA/spoT, and $\mathrm{relA} / \mathrm{spoT} / \mathrm{fpRel}$ mutants.}

Deletion mutants of relA, relA/spoT, and relA/spoT/fpRel were generated using splice overlap extension mutagenesis (Heckman and Pease 2007). Briefly, 1-kb upstream and downstream fragments of relA, spoT, and fpRel in DC3000 were amplified using primers specific to these genes. These primers also contained an

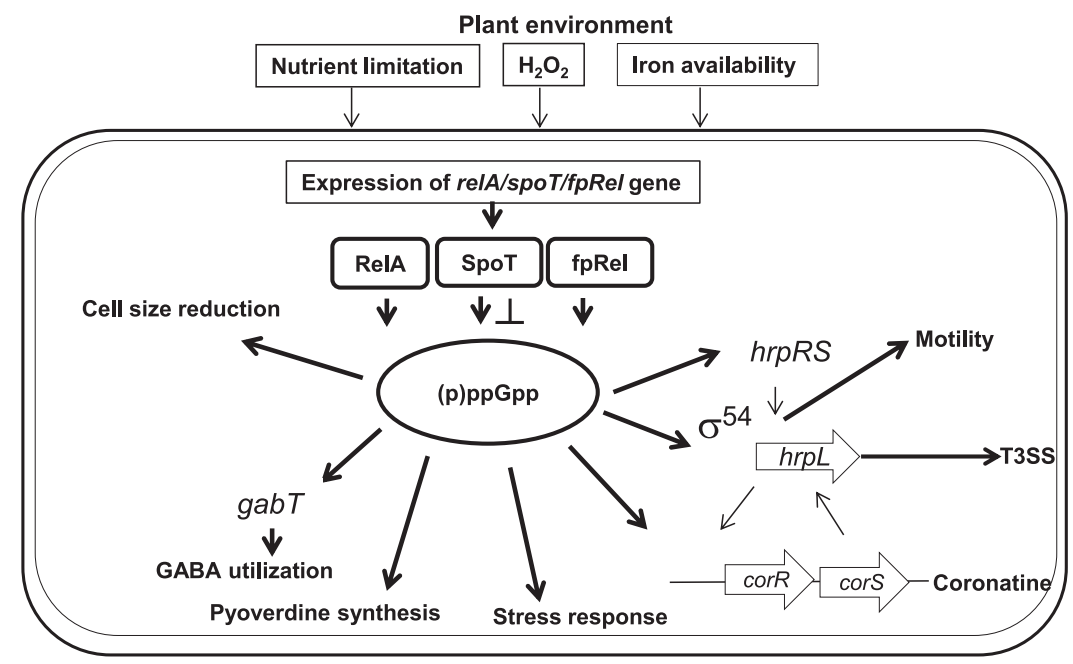

Fig. 8. A working model illustrating the role of ppGpp in Pseudomonas syringae pv. tomato DC3000 (DC3000) in response to plant and environmental stimuli. This model is based on findings obtained in this study as well as those reported in previous studies (Chatterjee et al. 2003; Peñaloza-Vázquez et al. 2000; Sreedharan et al. 2006; Takeuchi et al. 2012; Tang et al. 2006). The down arrows indicate positive effects and the intersecting lines a negative effect; bold lines indicate results from this study. $\sigma^{54}=\mathrm{RpoN}$ and CorRS $=$ regulators of coronatine. 
extension sequence complementary to a kanamycin resistance cassette flanked with FLP recombination target (FRT) sites from pKD13. The two PCR fragments contained ends overlapping with those of the kanamycin-resistance cassette (Datsenko and Wanner 2000). The two amplicons were then ligated with the kanamycin-resistance cassette, using overlap extension PCR. The final fragment was then cloned into the pTok2 vector

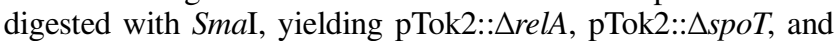
pTok2:: $\Delta f p R e l$, respectively. Each of these plasmids was electroporated into DC3000, and transformants were plated on KB plates containing kanamycin. Those kanamycin-resistant but tetracycline-sensitive mutants were selected. Gene disruption was confirmed using PCR, using primers specific to sequences flanking each of the genes. To generate markerless mutant strains, plasmid pFLP2- $\Omega$ expressing an FLP recombinase, was electroporated into the mutant strains. Transformants were plated on $\mathrm{KB}$ plates containing spectinomycin to allow for Flp recombinase-mediated recombination between the FRT sites, thus resulting in loss of the kanamycin-resistance cassette. The pFLP2- $\Omega$ plasmid was cured from these mutants by replicaplating on KB plates. Markerless deletions were confirmed by PCR. To generate a relA/spoT double mutant, plasmid pTok $2:$ : $\triangle s p o T$ was transferred to the relA markerless mutant strain via conjugation. For a relA/spoT/fpRel triple mutant, the plasmid pTok2:: $\triangle f p$ Rel was transferred to the relA/spoT markerless mutant strain.

\section{Mutant complementation.}

For complementation of mutants, a 3.0-kb fragment containing the native promoter and the relA gene, a $2.9-\mathrm{kb}$ fragment containing the native promoter and the spoT and rpoZ genes, and a 2.4-kb fragment containing the native promoter and fpRel gene were amplified using the primer pairs RelAcom-F(Bam $\mathrm{HI})$ and RelAcom-R (BamHI), SpoTcom-F(BamHI) and SpoTcom-R $($ BamHI), and FpRelAcom-F(SalI) and FpRelAcom-R(SalI), respectively. PCR fragments were digested with corresponding restriction enzymes and were cloned into the pVSP61 vector to yield plasmids pRelA, pSpoT, and pFpRel. These were then introduced into corresponding marker-less mutant strains by electroporation.

\section{Nucleotide extraction and ppGpp measurement by LC-MS/MS.}

Bacterial strains were grown in $100 \mathrm{ml}$ of $\mathrm{KB}$ to an $\mathrm{OD}_{600}$ of approximately 1 . Cells were harvested by centrifugation at 4,000 rpm, using an Eppendorf S5810 R centrifuge, for $15 \mathrm{~min}$ and were washed with $5 \mathrm{ml}$ of HMM medium. Cell pellets were resuspended in $100 \mathrm{ml}$ of HMM medium and were incubated with shaking at $250 \mathrm{rpm}$ at $22^{\circ} \mathrm{C}$ for $30 \mathrm{~min}$. Subsequently, bacterial cells were pelleted, and cells were immediately suspended in $2 \mathrm{ml}$ of $100 \%$ cold methanol, were vortexed for $50 \mathrm{~s}$, were frozen in liquid nitrogen, and were allowed to thaw on ice. Cell suspensions were then centrifuged at 4,000 rpm for $10 \mathrm{~min}$ at $4^{\circ} \mathrm{C}$. Supernatants were transferred to a new tube and were stored on ice. Then, $2 \mathrm{ml}$ of $100 \%$ cold methanol was added to the pellet. The freeze-thaw cycle was repeated, and the methanol extract was combined and, then, was filtered using a $0.22-\mu \mathrm{m}$ pore size filter (Millipore, Bedford, MA, U.S.A.). The filtrate was freeze-dried and resuspended in $200 \mu \mathrm{l}$ of distilled water for LCMS/MS analysis. Pure ppGpp, purchased from TriLink Biotech Inc. (San Diego, CA, U.S.A.), was used as a positive control.

Nucleotide-enriched samples were analyzed in a 5500 QTRAP LC-MS/MS system (AB Sciex) using a 1200 series HPLC system (Agilent Technologies, Santa Clara, CA, U.S.A.), including a degasser, an autosampler, and a binary pump. The LC separation was performed on an Agilent SB-Aq column $(4.6 \times 50 \mathrm{~mm}$, $5 \mu \mathrm{m})$ with a mobile phase $\mathrm{A}$ ( $10 \mathrm{mM}$ ammonia formate in water) and a mobile phase $\mathrm{B}$ (methanol). The flow rate was $0.3 \mathrm{ml} / \mathrm{min}$. The linear gradient was as follows: 0 to $4 \mathrm{~min}, 99 \% \mathrm{~A} ; 4.1$ to $8.0 \mathrm{~min}, 5 \% \mathrm{~A}$; and 8.1 to $13.0 \mathrm{~min}, 99 \% \mathrm{~A}$. The autosampler was set at $5^{\circ} \mathrm{C}$. The injection volume was $10 \mu \mathrm{l}$. Mass spectra were acquired under positive electrospray ionization with an ion spray voltage of $+5,500 \mathrm{~V}$. The source temperature was $450^{\circ} \mathrm{C}$. The curtain gas, ion source gas 1 , and ion source gas 2 were 35,65 , and 55 psi, respectively. Multiple reaction monitoring was used for quantification of $\mathrm{ppGpp}(\mathrm{m} / \mathrm{z} 604.1 \rightarrow \mathrm{m} / \mathrm{z} 152.0)$. The final ppGpp concentration was normalized to $\mathrm{OD}_{600}$.

Table 3. Bacterial strains and plasmids used in this study

\begin{tabular}{|c|c|c|}
\hline $\begin{array}{l}\text { Bacterial strain or } \\
\text { plasmid }\end{array}$ & Relevant characteristic ${ }^{a}$ & $\begin{array}{l}\text { Reference or } \\
\text { source }\end{array}$ \\
\hline \multicolumn{3}{|l|}{$\begin{array}{l}\text { syringae } \mathrm{pv} . \\
\text { tomato }\end{array}$} \\
\hline DC3000 & Wild type & \\
\hline$\Delta r e l A$ & $\begin{array}{l}\mathrm{Km}^{\mathrm{r}} \text {, relA::Kan, DC } 3000 \\
\text { derivative }\end{array}$ & This study \\
\hline$\Delta$ relA/spoT & $\begin{array}{l}\mathrm{Km}^{\mathrm{r}} \text {, relA and spoT }:: \mathrm{Kan}, \\
\mathrm{DC} 3000 \text { derivative }\end{array}$ & This study \\
\hline$\Delta r e l A / s p o T / f p R e l$ & $\begin{array}{l}\mathrm{Km}^{\mathrm{r}} \text {, relA, spoT and } f p \mathrm{Rel}^{-}:: \\
\mathrm{Kan}, \mathrm{DC} 3000 \text { derivative }\end{array}$ & This study \\
\hline \multicolumn{3}{|l|}{ Escherichia coli } \\
\hline DH10B & $\begin{array}{c}F^{-} \text {mcrA } \Delta(\text { mrr-hsdRMS- } \\
\text { mcrBC) } \Phi 80 l a c Z \Delta M 15 \\
\Delta \text { lacX74 recA1 endA1 } \\
\text { ara } 139 \Delta(\text { ara, leu } 7697 \\
\text { galU galK } \lambda \text {-rpsL }(\text { StrR }) \\
\text { nupG }\end{array}$ & Invitrogen \\
\hline DH5 $\alpha$ & $\begin{array}{c}F^{-} \phi 80 l a c Z \Delta M 15 \triangle(\text { lacZYA- } \\
\text { argF)U169 recA1 endA1 } \\
\text { hsdR17(rk-, mk+) phoA } \\
\text { supE44 thi-1 gyrA96 relA1 } \lambda\end{array}$ & Invitrogen \\
\hline \multicolumn{3}{|l|}{ Plasmids } \\
\hline pTok2 & $\begin{array}{l}\text { ColE1 replicon, suicide } \\
\text { plasmid, } \mathrm{Tc}^{\mathrm{r}}\end{array}$ & $\begin{array}{l}\text { Kitten and Willis } \\
1996\end{array}$ \\
\hline pKD13 & $\begin{array}{l}\text { FRT-Kan-FRT, oriR6K; Ap }{ }^{r} \text {, } \\
\mathrm{Km}^{\mathrm{r}}\end{array}$ & $\begin{array}{l}\text { Datsenko and } \\
\text { Wanner } 2000\end{array}$ \\
\hline pVSP61 & $\begin{array}{l}\text { Broad-host-range plasmid with } \\
\text { replicons of pVS1 and } \\
\text { pACYC184, } \mathrm{Km}^{\mathrm{r}}\end{array}$ & $\begin{array}{l}\text { Loper and Lindow } \\
1994\end{array}$ \\
\hline pFLP2-omega & $\begin{array}{l}\text { Suicide vector encoding flp } \\
\text { recombinase (the omega } \\
\text { fragment conferring } \\
\text { spectinomycin resistance had } \\
\text { been added into pFLP2); } \mathrm{Sp}^{\mathrm{r}}\end{array}$ & $\begin{array}{l}\text { R. Scott, } \\
\text { unpublished data }\end{array}$ \\
\hline pKT-trp & $\begin{array}{l}\text { gfp marker gene driven by the } \\
\text { trp promoter from Salmonella } \\
\text { typhimurium cloned into the } \\
\text { stable plasmid vector } \\
\text { pPROBE-KT }\end{array}$ & $\begin{array}{l}\text { Monier and } \\
\text { Lindow 2003a }\end{array}$ \\
\hline pAvrPto-gfp & $\begin{array}{l}\text { avrPto effector promoter fused } \\
\text { to GFP }\end{array}$ & Xiao et al. 2004 \\
\hline 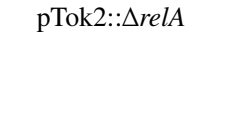 & $\begin{array}{l}\Delta r e l A:: \text { Kan from overlapping } \\
\text { polymerase chain reaction } \\
\text { (PCR) cloned into pTok2; } \mathrm{Tc}^{\mathrm{r}} \text {, } \\
\mathrm{Km}^{\mathrm{r}}\end{array}$ & This study \\
\hline pTok2:: $\Delta$ spoT & $\begin{array}{l}\Delta \text { spoT::Kan from overlapping } \\
\text { PCR cloned into pTok2; } \mathrm{Tc}^{\mathrm{r}} \text {, } \\
\mathrm{Km}^{\mathrm{r}}\end{array}$ & This study \\
\hline pTok2:: $\Delta f p R e l$ & $\begin{array}{l}\Delta f p \text { Rel::Kan from overlapping } \\
\text { PCR cloned into pTok } 2 ; \mathrm{Tc}^{\mathrm{r}} \text {, } \\
\mathrm{Km}^{\mathrm{r}}\end{array}$ & This study \\
\hline pRelA & $\begin{array}{l}\text { relA gene with native promoter } \\
\text { cloned into pVSP61 } \mathrm{Km}^{\mathrm{r}}\end{array}$ & This study \\
\hline pSpoT & $\begin{array}{l}\text { spoT gene with native promoter } \\
\text { cloned into pVSP61 } \mathrm{Km}^{\mathrm{r}}\end{array}$ & This study \\
\hline pFpRel & $\begin{array}{l}\text { spoT gene with native promoter } \\
\text { cloned into pVSP61 } \mathrm{Km}^{\mathrm{r}}\end{array}$ & This study \\
\hline
\end{tabular}

${ }^{\mathrm{a}} \mathrm{Km}^{\mathrm{r}}, \mathrm{Tc}^{\mathrm{r}}, \mathrm{Ap}^{\mathrm{r}}$, and $\mathrm{Sp}^{\mathrm{r}}$ correspond to kanamycin, tetracycline, ampicillin and spectinomycin resistance, respectively. 


\section{RNA isolation and qRT-PCR.}

Bacterial strains grown overnight at $28^{\circ} \mathrm{C}$ in $\mathrm{KB}$ medium were harvested by centrifugation, were washed with phosphate buffered saline (PBS), were reinoculated in either HMM or modified MG medium (replacing mannitol and L-glutamic acid in MG medium with $10 \mathrm{mM} \mathrm{GABA}$ ), and were grown for $3 \mathrm{~h}$. An RNA protect reagent (Qiagen, Hilden, Germany) was added to bacterial cells and total RNA was extracted using the RNeasy Mini BacteriaProtect kit (Qiagen). DNA was removed using the Turbo DNA-free kit (Ambion, Austin, TX, U.S.A.). RNA samples were quantified using a Nano-Drop ND-100 spectrophotometer (Nano-Drop Technologies, Wilmington, DE, U.S.A.). cDNA was synthesized from $1 \mu \mathrm{g}$ of RNA using SuperScript III (Invitrogen Life Technologies, Carlsbad, CA, U.S.A.) and random hexamers. qRT-PCR was performed using $100 \mathrm{ng}$ of cDNA and a Power SYBR Green PCR Master Mix on a StepOnePlus Real-Time PCR System (Applied Biosystems, Foster City, CA, U.S.A.), following the manufacturer's specifications. Melting curve analysis was used to verify amplification of a single product. Gene expression was calculated using the relative quantification ( $\Delta \Delta \mathrm{Ct}$ [cycle threshold]) method. The $\mathrm{Ct}$ values of each gene were normalized to $\mathrm{Ct}$ values of the housekeeping sigma factor gene $r p o D$.

\section{Flow cytometry analysis.}

Bacterial cells were analyzed by flow cytometry (BD Biosciences, San Jose, CA, U.S.A.) as describe previously (Wang et al. 2009; Zhao et al. 2009). The WT and mutant strains containing the pAvrPto-GFP plasmid were grown overnight in $\mathrm{KB}$ and were harvested, washed, and resuspended in either HMM or HMM supplemented with $10 \mathrm{mM}$ of amino acids. Bacteria cells were incubated in an appropriate medium for either 3 or $5 \mathrm{~h}$ at $18^{\circ} \mathrm{C}$. Subsequently, bacterial cells were diluted in PBS for flow cytometry assay. Flow cytometry was performed using an LSRII 10-parameter multilaser analyzer (BD Biosciences). Data were collected for a total of 100,000 events and were analyzed statistically by gating, using flow cytometry software FCS Express V3 (De Novo Software, Los Angeles). A geometric mean was calculated for each sample, and the experiment was repeated three times.

\section{Swarming motility, pyoverdine production, oxidative stress, and GABA utilization assay.}

For the swarming motility assay, cells were grown overnight in $\mathrm{KB}$ and were harvested and washed in PBS. Cells were resuspended in PBS to a final concentration of $\mathrm{OD}_{600}=0.3$. A total of $10 \mu \mathrm{l}$ was spotted onto the center of swarming plates $(0.4 \% \mathrm{~KB}$ agar), and plates were incubated for $24 \mathrm{~h}$ at room temperature. Motility of bacterial cells was visually examined.

For pyoverdine production, bacterial cells of overnight cultures in $\mathrm{KB}$ were washed, were resuspended to an $\mathrm{OD}_{600}$ of 0.05 in MG medium, and were incubated along with shaking at $28^{\circ} \mathrm{C}$ for $24 \mathrm{~h}$. Pyoverdine from supernatants was measured at $\mathrm{OD}_{405}$, and were normalized by $\mathrm{OD}_{600}$ (Imperi et al. 2009).

For oxidative stress assay, bacterial cells were grown in KB medium, were washed, and were resuspended in PBS buffer with or without $1 \mathrm{mM} \mathrm{H}_{2} \mathrm{O}_{2}$ to a final concentration of approximately $1.0 \times 10^{8} \mathrm{CFU}$ per milliliter (Yu et al. 2013). We selected this concentration of $\mathrm{H}_{2} \mathrm{O}_{2}$ so that more than $99 \%$ of the triple mutant would not survive. Bacterial suspensions were then incubated at room temperature for $15 \mathrm{~min}$. Subsequently, serial dilutions were plated on KB agar to enumerate surviving cells. Percent survival was calculated by dividing $\mathrm{H}_{2} \mathrm{O}_{2}$ treated versus untreated cells.

For the GABA utilization assay, bacterial cells of overnight cultures in $\mathrm{KB}$ were washed and resuspended to an $\mathrm{OD}_{600}$ of 0.02 in modified MG medium with $10 \mathrm{mM} \mathrm{GABA}$. Cells were grown overnight at $28^{\circ} \mathrm{C}$, and growth was monitored by measuring $\mathrm{OD}_{600}$.
Virulence assay and bacterial growth in tomato.

Virulence of DC3000 and its mutants was assessed on tomato (Lycopersicon esculentum), following spray inoculation. Briefly, bacterial cells were grown overnight in KB broth, were harvested by centrifugation, and were resuspended in PBS buffer with bacterial cells adjusted to an $\mathrm{OD}_{600}$ of 0.1 (approximately $10^{8}$ CFU per milliliter). Bacterial cells were sprayed onto tomato plants (approximately 4 weeks old) until leaf surfaces were uniformly wet. For the first $24 \mathrm{~h}$ following inoculation, plants were covered with plastic tents to maintain high humidity and moisture. Inoculated plants were maintained in a greenhouse at $25^{\circ} \mathrm{C}$ for 7 days. Symptoms were recorded at 7 dpi. The experiments were repeated at least three times with similar results. For bacterial growth, four leaves were randomly collected from each plant at a given time point. Leaves were weighed separately and were macerated in PBS, using a mortar and pestle. Serial dilutions were made in PBS and were plated on KB agar medium amended with appropriate antibiotics. Cell numbers were calculated after enumeration of colonies on plates incubated at $28^{\circ} \mathrm{C}$ for $48 \mathrm{~h}$.

\section{Determination of cell lengths}

\section{by epifluorescence microscopy.}

Lengths of $P$. syringae cells were determined by epifluorescence microscopy. Bacterial strains constitutively expressing GFP were grown in $\mathrm{KB}$ to mid exponential phase $\left(\mathrm{OD}_{600}=0.7\right)$ and were harvested, washed, and reinoculated at $\mathrm{OD}_{600}=0.1$ in either KB broth or in HMM. After $4 \mathrm{~h}, 3 \mu \mathrm{l}$ of bacterial suspension was mixed with $5 \mu$ l of Aqua-Polymount (Polysciences, Warrington, PA, U.S.A.), was mounted between cover slips, and was immediately observed under an Axiovert 200M fluorescence microscope (Carl Zeiss, Jena, Germany) using FITC filter sets (absorbance: 490 to $494 \mathrm{~nm}$; emission: $517 \mathrm{~nm}$ ). Images were captured with an AxioCam MPc digital camera (Carl Zeiss). At least 200 individual cells from 10 different images were measured using ImageJ software available online at the National Institutes of Health.

\section{Determination of cell viability by confocal microscopy.}

Bacterial cell viability on leaf surfaces was observed using a confocal laser scanning microscope (Zeiss). Suspensions of bacterial strains harboring pKT-trp or pAvrPto-GFP in PBS buffer $\left(\mathrm{OD}_{600}=0.1\right)$ were sprayed onto tomato (host) and tobacco (nonhost) leaves that were incubated under controlled conditions at $22^{\circ} \mathrm{C}$. Plants were held under plastic tents for $24 \mathrm{hpi}$ to maintain high humidity and moisture. Two plants were inoculated simultaneously, and leaves were randomly sampled from plants at each time point. Leaf discs (12 $\mathrm{mm}$ diameter) were mounted between cover slips $(22 \times 50-1)$ in Aqua-Polymount (Polysciences) and were mixed with $5 \mu \mathrm{l}$ of propidium iodide $(10 \mu \mathrm{g} / \mathrm{ml})$. Samples were kept in the dark at room temperature for $15 \mathrm{~min}$ and were observed by an LSM 700 laser scanning microscope (Zeiss), using a $20 \times$ objective. At least six leaf discs were evaluated per strain at each time point. Images were obtained by mixing the signals recorded in two excitation lines (488-nm laser for GFP fluorescence and 568-nm laser for chloroplastic autofluorescence and propidium iodide emission). At least 10 randomly selected fields were examined for viability of bacterial cells on leaf surfaces.

\section{ACKNOWLEDGMENTS}

We would like to thank S. Lindow at the University of California Berkeley and J. Greenberg at the University of Chicago for providing plasmids. We also thank R. Zielinski at the University of Illinois for his help with epifluorescence microscope. This project was supported by the Agriculture and Food Research Initiative Competitive Grants Program grant number 2010-6511020497 from the United States Department of Agriculture (USDA) National Institute of Food and Agriculture (YFZ) and USDA Specialty Crop Research 
Initiative grant AG 2009-51181-06023 (S. S. Korban) and Office of Research project 65-325. The 5500 QTRAP LC-MS/MS system is funded by the National Institutes of Health National Center for Research Resources grant S10RR024516 (Z. Li)

\section{LITERATURE CITED}

Aberg, A., Shingler, V., and Balsalobre, C. 2006. (p)ppGpp regulates type 1 fimbriation of Escherichia coli by modulating the expression of the sitespecific recombinase FimB. Mol. Microbiol. 60:1520-1533.

Alarcón-Chaidez, F. J., Keith, L., Zhao, Y., and Bender, C. L. 2003. RpoN $(\sigma(54))$ is required for plasmid-encoded coronatine biosynthesis in Pseudomonas syringae. Plasmid 49:106-117.

Alfano, J. R., and Collmer, A. 2004. Type III secretion system effector proteins: Double agents in bacterial disease and plant defense. Annu. Rev. Phytopathol. 42:385-414.

Anderson, J. C., Wan, Y., Kim, Y.-M., Pasa-Tolic, L., Metz, T. O., and Peck, S. C. 2014. Decreased abundance of type III secretion system-inducing signals in Arabidopsis mkpl enhances resistance against Pseudomonas syringae. Proc. Natl. Acad. Sci. U.S.A. 111:6846-6851.

Atkinson, G. C., Tenson, T., and Hauryliuk, V. 2011. The RelA/SpoT homolog (RSH) superfamily: Distribution and functional evolution of ppGpp synthetases and hydrolases across the tree of life. PLoS ONE 6 : e23479.

Barker, M. M., Gaal, T., and Gourse, R. L. 2001. Mechanism of regulation of tranption initiation by ppGpp. II. Models for positive control based on properties of RNAP mutants and competition for RNAP. J. Mol. Biol. 305:689-702.

Bernardo, L. M. D., Johansson, L. U. M., Solera, D., Skärfstad, E., and Shingler, V. 2006. The guanosine tetraphosphate (ppGpp) alarmone, DksA and promoter affinity for RNA polymerase in regulation of sigmadependent transcription. Mol. Microbiol. 60:749-764.

Boureau, T., Routtu, J., Roine, E., Taira, S., and Romantschuk, M. 2002. Localization of hrpA-induced Pseudomonas syringae pv. tomato DC3000 in infected tomato leaves. Mol. Plant Pathol. 3:451-460.

Bowden, S. D., Eyres, A., Chung, J. C. S., Monson, R. E., Thompson, A., Salmond, G. P. C., Spring, D. R., and Welch, M. 2013. Virulence in Pectobacterium atrosepticum is regulated by a coincidence circuit involving quorum sensing and the stress alarmone, (p)ppGpp. Mol. Microbiol. 90:457-471.

Bremer, H., and Ehrenberg, M. 1995. Guanosine tetraphosphate as a global regulator of bacterial RNA synthesis: A model involving RNA polymerase pausing and queuing. Biochim. Biophys. Acta 1262:15-36.

Bretz, J., Losada, L., Lisboa, K., and Hutcheson, S. W. 2002. Lon protease functions as a negative regulator of type III protein secretion in Pseudomonas syringae. Mol. Microbiol. 45:397-409.

Brooks, D. M., Hernández-Guzmán, G., Kloek, A. P., Alarcón-Chaidez, F., Sreedharan, A., Rangaswamy, V., Peñaloza-Vázquez, A., Bender, C. L., and Kunkel, B. N. 2004. Identification and characterization of a welldefined series of coronatine biosynthetic mutants of Pseudomonas syringae pv. tomato DC3000. Mol. Plant Microbe Interact. 17:162-174.

Buell, C. R., Joardar, V., Lindeberg, M., Selengut, J., Paulsen, I. T., Gwinn, M. L., Dodson, R. J., Deboy, R. T., Durkin, A. S., Kolonay, J. F., Madupu, R., Daugherty, S., Brinkac, L., Beanan, M. J., Haft, D. H., Nelson, W. C., Davidsen, T., Zafar, N., Zhou, L., Liu, J., Yuan, Q., Khouri, H., Fedorova, N., Tran, B., Russell, D., Berry, K., Utterback, T., Van Aken, S. E., Feldblyum, T. V., D’Ascenzo, M., Deng, W.-L., Ramos, A. R., Alfano, J. R., Cartinhour, S., Chatterjee, A. K., Delaney, T. P., Lazarowitz, S. G., Martin, G. B., Schneider, D. J., Tang, X., Bender, C. L., White, O., Fraser, C. M., and Collmer, A. 2003. The complete genome sequence of the Arabidopsis and tomato pathogen Pseudomonas syringae pv. tomato DC3000. Proc. Natl. Acad. Sci. U.S.A. 100:10181-10186.

Chang, D.-E., Smalley, D. J., and Conway, T. 2002. Gene expression profiling of Escherichia coli growth transitions: An expanded stringent response model. Mol. Microbiol. 45:289-306.

Chatterjee, A., Cui, Y., Yang, H., Collmer, A., Alfano, J. R., and Chatterjee, A. K. 2003. GacA, the response regulator of a two-component system, acts as a master regulator in Pseudomonas syringae pv. tomato DC3000 by controlling regulatory RNA, transcriptional activators, and alternate sigma factors. Mol. Plant Microbe Interact. 16:1106-1117.

Chevrot, R., Rosen, R., Haudecoeur, E., Cirou, A., Shelp, B. J., Ron, E., and Faure, D. 2006. GABA controls the level of quorum-sensing signal in Agrobacterium tumefaciens. Proc. Natl. Acad. Sci. U.S.A. 103: 7460-7464.

Collmer, A., Badel, J. L., Charkowski, A. O., Deng, W. L., Fouts, D. E., Ramos, A. R., Rehm, A. H., Anderson, D. M., Schneewind, O., van Dijk, K., and Alfano, J. R. 2000. Pseudomonas syringae Hrp type III secretion system and effector proteins. Proc. Natl. Acad. Sci. U.S.A. 97: 8770-8777.

Costanzo, A., Nicoloff, H., Barchinger, S. E., Banta, A. B., Gourse, R. L. and Ades, S. E. 2008. ppGpp and DksA likely regulate the activity of the extracytoplasmic stress factor sigmaE in Escherichia coli by both direct and indirect mechanisms. Mol. Microbiol. 67:619-632.

Crompton, M. J., Dunstan, R. H., Macdonald, M. M., Gottfries, J., von Eiff, C., and Roberts, T. K. 2014. Small changes in environmental parameters lead to alterations in antibiotic resistance, cell morphology and membrane fatty acid composition in Staphylococcus lugdunensis. PLoS ONE 9:e92296.

Dalebroux, Z. D., and Swanson, M. S. 2012. ppGpp: Magic beyond RNA polymerase. Nat. Rev. Microbiol. 10:203-212.

Dalebroux, Z. D., Svensson, S. L., Gaynor, E. C., and Swanson, M. S. 2010. ppGpp conjures bacterial virulence. Microbiol. Mol. Biol. Rev. 74: 171-199.

Datsenko, K. A., and Wanner, B. L. 2000. One-step inactivation of chromosomal genes in Escherichia coli $\mathrm{K}-12$ using PCR products. Proc. Natl. Acad. Sci. U.S.A. 97:6640-6645.

Eichel, J., Chang, Y. Y., Riesenberg, D., and Cronan, J. E., Jr. 1999. Effect of ppGpp on Escherichia coli cyclopropane fatty acid synthesis is mediated through the RpoS sigma factor (sigmaS). J. Bacteriol. 181: 572-576.

Elizabeth, S. V., and Bender, C. L. 2007. The phytotoxin coronatine from Pseudomonas syringae pv. tomato DC3000 functions as a virulence factor and influences defence pathways in edible brassicas. Mol. Plant Pathol. 8:83-92.

Ferreira, A. O., Myers, C. R., Gordon, J. S., Martin, G. B., Vencato, M., Collmer, A., Wehling, M. D., Alfano, J. R., Moreno-Hagelsieb, G., Lamboy, W. F., DeClerck, G., Schneider, D. J., and Cartinhour, S. W. 2006. Whole-genome expression profiling defines the HrpL regulon of Pseudomonas syringae pv. tomato DC3000, allows de novo reconstruction of the Hrp cis clement, and identifies novel coregulated genes. Mol Plant Microbe Interact. 19:1167-1179.

Gummesson, B., Magnusson, L. U., Lovmar, M., Kvint, K., Persson, O., Ballesteros, M., Farewell, A., and Nyström, T. 2009. Increased RNA polymerase availability directs resources towards growth at the expense of maintenance. EMBO (Eur. Mol. Biol. Organ.) J. 28:2209-2219.

Hase, C. 1999. Nutrient deprivation and the subsequent survival of biocontrol Pseudomonas fluorescens CHA0 in soil. Soil Biol. Biochem. 31:1181-1188.

Haseltine, W. A., and Block, R. 1973. Synthesis of guanosine tetra- and pentaphosphate requires the presence of a codon-specific, uncharged transfer ribonucleic acid in the acceptor site of ribosomes. Proc. Natl Acad. Sci. U.S.A. 70:1564-1568.

Heckman, K. L., and Pease, L. R. 2007. Gene splicing and mutagenesis by PCR-driven overlap extension. Nat. Protoc. 2:924-932.

Hendrickson, E. L., Guevera, P., and Ausubel, F. M. 2000a. The alternative sigma factor RpoN is required for hrp activity in Pseudomonas syringae pv. maculicola and acts at the level of hrpL transcription. J. Bacteriol. 182:3508-3516.

Hendrickson, E. L., Guevera, P., Peñaloza-Vàzquez, A., Shao, J., Bender, C., and Ausubel, F. M. 2000b. Virulence of the phytopathogen Pseudomonas syringae pv. maculicola is rpoN dependent. J. Bacteriol. 182:3498-3507

Hernandez, V. J., and Bremer, H. 1993. Characterization of RNA and DNA synthesis in Escherichia coli strains devoid of ppGpp. J. Biol. Chem. 268:10851-10862.

Huynh, T. V., Dahlbeck, D., and Staskawicz, B. J. 1989. Bacterial blight of soybean: Regulation of a pathogen gene determining host cultivar specificity. Science 245:1374-1377.

Imperi, F., Tiburzi, F., and Visca, P. 2009. Molecular basis of pyoverdine siderophore recycling in Pseudomonas aeruginosa. Proc. Natl. Acad. Sci. U.S.A. 106:20440-20445.

Johansson, J., Balsalobre, C., Wang, S.-Y., Urbonaviciene, J., Jin, D. J. Sondén, B., and Uhlin, B. E. 2000. Nucleoid proteins stimulate stringently controlled bacterial promoters: A link between the cAMPCRP and the (p)ppGpp regulons in Escherichia coli. Cell 102:475-485.

Jovanovic, M., James, E. H., Burrows, P. C., Rego, F. G. M., Buck, M., and Schumacher, J. 2011. Regulation of the co-evolved HrpR and HrpS AAA+ proteins required for Pseudomonas syringae pathogenicity. Nat. Commun. 2:177.

Jubair, M., Morris, J. G., Jr., and Ali, A. 2012. Survival of Vibrio cholerae in nutrient-poor environments is associated with a novel "persister" phenotype. PLoS ONE 7:e45187.

Khakimova, M., Ahlgren, H. G., Harrison, J. J., English, A. M., and Nguyen, D. 2013. The stringent response controls catalases in 
Pseudomonas aeruginosa and is required for hydrogen peroxide and antibiotic tolerance. J. Bacteriol. 195:2011-2020.

Kim, B. J., Schneider, D. J., Cartinhour, S. W., and Shuler, M. L. 2010. Complex responses to culture conditions in Pseudomonas syringae pv. tomato DC3000 continuous cultures: The role of iron in cell growth and virulence factor induction. Biotechnol. Bioeng. 105:955-964.

Kitten, T., and Willis, D. K. 1996. Suppression of a sensor kinase-dependent phenotype in Pseudomonas syringae by ribosomal proteins L35 and L20. J. Bacteriol. 178:1548-1555.

Lan, L., Deng, X., Xiao, Y., Zhou, J.-M., and Tang, X. 2007. Mutation of Lon protease differentially affects the expression of Pseudomonas syringae type III secretion system genes in rich and minimal media and reduces pathogenicity. Mol. Plant Microbe Interact. 20:682-696.

Loper, J. E., and Lindow, S. E. 1994. A biological sensor for iron available to bacteria in their habitats on plant surfaces. Appl. Environ. Microbiol. 60:1934-1941.

Maciąg-Dorszyńska, M., Szalewska-Pałasz, A., and Wegrzyn, G. 2013. Different effects of ppGpp on Escherichia coli DNA replication in vivo and in vitro. FEBS (Fed. Eur. Biochem. Soc.) Open Bio 3:161-164.

Magnusson, L. U., Farewell, A., and Nyström, T. 2005. ppGpp: A global regulator in Escherichia coli. Trends Microbiol. 13:236-242.

Magnusson, L. U., Gummesson, B., Joksimović, P., Farewell, A., and Nyström, T. 2007. Identical, independent, and opposing roles of ppGpp and DksA in Escherichia coli. J. Bacteriol. 189:5193-5202.

Manceau, C., and Horvais, A. 1997. Assessment of genetic diversity among strains of Pseudomonas syringae by PCR-restriction fragment length polymorphism analysis of rRNA operons with special emphasis on P. syringae pv. tomato. Appl. Environ. Microbiol. 63: 498-505.

Markel, E., Maciak, C., Butcher, B. G., Myers, C. R., Stodghill, P., Bao, Z., Cartinhour, S., and Swingle, B. 2011. An extracytoplasmic function sigma factor-mediated cell surface signaling system in Pseudomonas syringae pv. tomato DC3000 regulates gene expression in response to heterologous siderophores. J. Bacteriol. 193:5775-5783.

Markel, E., Butcher, B. G., Myers, C. R., Stodghill, P., Cartinhour, S., and Swingle, B. 2013. Regulons of three Pseudomonas syringae pv. tomato DC3000 iron starvation sigma factors. Appl. Environ. Microbiol. 79: 725-727.

Melotto, M., Underwood, W., and He, S. Y. 2008. Role of stomata in plant innate immunity and foliar bacterial diseases. Annu. Rev. Phytopathol. 46:101-122.

Monier, J.-M., and Lindow, S. E. 2003a. Differential survival of solitary and aggregated bacterial cells promotes aggregate formation on leaf surfaces. Proc. Natl. Acad. Sci. U.S.A. 100:15977-15982.

Monier, J.-M., and Lindow, S. E. 2003b. Pseudomonas syringae responds to the environment on leaves by cell size reduction. Phytopathology 93: 1209-1216.

Moore, R. A., Starratt, A. N., Ma, S.-W., Morris, V. L., and Cuppels, D. A. 1989. Identification of a chromosomal region required for biosynthesis of the phytotoxin coronatine by Pseudomonas syringae pv. tomato. Can. J. Microbiol. 35:910-917.

Moris, M., Braeken, K., Schoeters, E., Verreth, C., Beullens, S., Vanderleyden, J., and Michiels, J. 2005. Effective symbiosis between Rhizobium etli and Phaseolus vulgaris requires the alarmone ppGpp. J. Bacteriol. 187:5460-5469.

Oguiza, J. A., Kiil, K., and Ussery, D. W. 2005. Extracytoplasmic function sigma factors in Pseudomonas syringae. Trends Microbiol. 13:565-568.

Ortiz-Martín, I., Thwaites, R., Mansfield, J. W., and Beuzón, C. R. 2010. Negative regulation of the Hrp type III secretion system in Pseudomonas syringae pv. phaseolicola. Mol. Plant Microbe Interact. 23:682-701

Park, D. H., Mirabella, R., Bronstein, P. A., Preston, G. M., Haring, M. A., Lim, C. K., Collmer, A., and Schuurink, R. C. 2010. Mutations in $\gamma$-aminobutyric acid (GABA) transaminase genes in plants or Pseudomonas syringae reduce bacterial virulence. Plant J. 64:318-330.

Peñaloza-Vázquez, A., Preston, G. M., Collmer, A., and Bender, C. L. 2000 Regulatory interactions between the Hrp type III protein secretion system and coronatine biosynthesis in Pseudomonas syringae pv. tomato DC3000. Microbiology 146:2447-2456.

Potrykus, K., and Cashel, M. 2008. (p)ppGpp: Still magical? Annu. Rev. Microbiol. 62:35-51.

Potrykus, K., Murphy, H., Philippe, N., and Cashel, M. 2011. ppGpp is the major source of growth rate control in E. coli. Environ. Microbiol. 13: 563-575.

Rahme, L. G., Mindrinos, M. N., and Panopoulos, N. J. 1992. Plant and environmental sensory signals control the expression of hrp genes in Pseudomonas syringae pv. phaseolicola. J. Bacteriol. 174:3499-3507.

Rico, A., and Preston, G. M. 2008. Pseudomonas syringae pv. tomato DC3000 uses constitutive and apoplast-induced nutrient assimilation pathways to catabolize nutrients that are abundant in the tomato apoplast. Mol. Plant Microbe Interact. 21:269-282.

Sambrook, J., Fritsch, E. F., and Maniatis, T. 1989. Molecular Cloning: A Laboratory Manual, 2nd Ed. Cold Spring Harbor Laboratory Press, Cold Spring Harbor, NY.

Selin, C., Habibian, R., Poritsanos, N., Athukorala, S. N. P., Fernando, D. and de Kievit, T. R. 2010. Phenazines are not essential for Pseudomonas chlororaphis PA23 biocontrol of Sclerotinia sclerotiorum, but do play a role in biofilm formation. FEMS Microbiol. Ecol. 71:73-83.

Sreedharan, A., Peñaloza-Vazquez, A., Kunkel, B. N., and Bender, C. L. 2006. CorR regulates multiple components of virulence in Pseudomonas syringae pv. tomato DC3000. Mol. Plant Microbe Interact. 19: 768-779.

Stauber, J. L., Loginicheva, E., and Schechter, L. M. 2012. Carbon source and cell density-dependent regulation of type III secretion system gene expression in Pseudomonas syringae pathovar tomato DC3000. Res. Microbiol. 163:531-539.

Steinberger, R. E., Allen, A. R., Hansa, H. G., and Holden, P. A. 2002. Elongation correlates with nutrient deprivation in Pseudomonas aeruginosa-unsaturates biofilms. Microb. Ecol. 43:416-423.

Szalewska-Palasz, A., Johansson, L. U. M., Bernardo, L. M. D., Skärfstad, E., Stec, E., Brännström, K., and Shingler, V. 2007. Properties of RNA polymerase bypass mutants: Implications for the role of ppGpp and its co-factor DksA in controlling transcription dependent on sigma54. J. Biol. Chem. 282:18046-18056.

Takeuchi, K., Yamada, K., and Haas, D. 2012. ppGpp controlled by the Gac/Rsm regulatory pathway sustains biocontrol activity in Pseudomonas fluorescens CHA0. Mol. Plant Microbe Interact. 25: 1440-1449.

Tang, X., Xiao, Y., and Zhou, J.-M. 2006. Regulation of the type III secretion system in phytopathogenic bacteria. Mol. Plant Microbe Interact. 19:1159-1166.

Traxler, M. F., Summers, S. M., Nguyen, H.-T., Zacharia, V. M., Hightower, G. A., Smith, J. T., and Conway, T. 2008. The global, ppGpp-mediated stringent response to amino acid starvation in Escherichia coli. Mol. Microbiol. 68:1128-1148.

Uppalapati, S. R., Ishiga, Y., Wangdi, T., Kunkel, B. N., Anand, A., Mysore, K. S., and Bender, C. L. 2007. The phytotoxin coronatine contributes to pathogen fitness and is required for suppression of salicylic acid accumulation in tomato inoculated with Pseudomonas syringae pv. tomato DC3000. Mol. Plant Microbe Interact. 20:955-965.

Vercruysse, M., Fauvart, M., Jans, A., Beullens, S., Braeken, K., Cloots, L., Engelen, K., Marchal, K., and Michiels, J. 2011. Stress response regulators identified through genome-wide transcriptome analysis of the (p)ppGpp-dependent response in Rhizobium etli. Genome Biol. 12 R17.

Vogt, S. L., Green, C., Stevens, K. M., Day, B., Erickson, D. L., Woods, D. E., and Storey, D. G. 2011. The stringent response is essential for Pseudomonas aeruginosa virulence in the rat lung agar bead and Drosophila melanogaster feeding models of infection. Infect. Immun. 79:4094-4104.

Wang, X., Alarcón-Chaidez, F., Peñaloza-Vázquez, A., and Bender, C. L. 2002. Differential regulation of coronatine biosynthesis in Pseudomonas syringae pv. tomato DC3000 and P. syringae pv. glycinea PG4180. Physiol. Mol. Plant Pathol. 60:111-120.

Wang, C., Zhang, H.-B., Wang, L.-H., and Zhang, L.-H. 2006. Succinic semialdehyde couples stress response to quorum-sensing signal decay in Agrobacterium tumefaciens. Mol. Microbiol. 62:45-56.

Wang, J., Gardiol, N., Burr, T., Salmond, G. P. C., and Welch, M. 2007. RelA-dependent (p)ppGpp production controls exoenzyme synthesis in Erwinia carotovora subsp. atroseptica. J. Bacteriol. 189: 7643-7652.

Wang, D., Korban, S. S., and Zhao, Y. 2009. The Rcs phosphorelay system is essential for pathogenicity in Erwinia amylovora. Mol. Plant Pathol. 10:277-290.

Wei, C.-F., Deng, W.-L., and Huang, H.-C. 2005. A chaperone-like HrpG protein acts as a suppressor of HrpV in regulation of the Pseudomonas syringae pv. syringae type III secretion system. Mol. Microbiol. 57: 520-536.

Whalen, M. C., Innes, R. W., Bent, A. F., and Staskawicz, B. J. 1991. Identification of Pseudomonas syringae pathogens of Arabidopsis and a bacterial locus determining avirulence on both Arabidopsis and soybean. Plant Cell 3:49-59.

Xiao, H., Kalman, M., Ikehara, K., Zemel, S., Glaser, G., and Cashel, M. 1991. Residual guanosine $3^{\prime}, 5^{\prime}$-bispyrophosphate synthetic activity of relA null mutants can be eliminated by spoT null mutations. J. Biol. Chem. 266:5980-5990. 
Xiao, Y., Lu, Y., Heu, S., and Hutcheson, S. W. 1992. Organization and environmental regulation of the Pseudomonas syringae pv. syringae 61 hrp cluster. J. Bacteriol. 174:1734-1741.

Xiao, F., Goodwin, S. M., Xiao, Y., Sun, Z., Baker, D., Tang, X., Jenks, M. A., and Zhou, J.-M. 2004. Arabidopsis CYP86A2 represses Pseudomonas syringae type III genes and is required for cuticle development. EMBO (Eur. Mol. Biol. Organ.) J. 23:2903-2913.

Xin, X.-F., and He, S. Y. 2013. Pseudomonas syringae pv. tomato DC3000: A model pathogen for probing disease susceptibility and hormone signaling in plants. Annu. Rev. Phytopathol. 51:473-498.

Yu, X., Lund, S. P., Scott, R. A., Greenwald, J. W., Records, A. H., Nettleton, D., Lindow, S. E., Gross, D. C., and Beattie, G. A. 2013. Transcriptional responses of Pseudomonas syringae to growth in epiphytic versus apoplastic leaf sites. Proc. Natl. Acad. Sci. U.S.A. 110:E425-E434.

Zhang, H.-B., Wang, C., and Zhang, L.-H. 2004. The quormone degradation system of Agrobacterium tumefaciens is regulated by starvation signal and stress alarmone (p)ppGpp. Mol. Microbiol. 52: 1389-1401.

Zhao, Y., Thilmony, R., Bender, C. L., Schaller, A., He, S. Y., and Howe, G. A. 2003. Virulence systems of Pseudomonas syringae pv. tomato promote bacterial speck disease in tomato by targeting the jasmonate signaling pathway. Plant J. 36:485-499.

Zhao, Y., Wang, D., Nakka, S., Sundin, G. W., and Korban, S. S. 2009. Systems level analysis of two-component signal transduction systems in Erwinia amylovora: Role in virulence, regulation of amylovoran biosynthesis and swarming motility. BMC Genomics 10:245.

\section{AUTHOR-RECOMMENDED INTERNET RESOURCE}

United States National Institutes of Health ImageJ software: http://rsb.info.nih.gov/ij 